\title{
A review of Uganda's national policies relevant to climate change adaptation and mitigation
}

Insights from Mount Elgon

Abwoli Y Banana

Patrick Byakagaba

Aaron JM Russell

Daniel Waiswa

Allan Bomuhangi

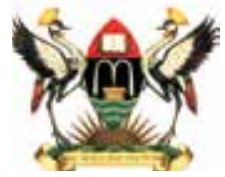





\title{
A review of Uganda's national policies relevant to climate change adaptation and mitigation
}

\author{
Insights from Mount Elgon
}

\author{
Abwoli Y Banana \\ School of Forestry, Environmental and Geographical Sciences, Makerere University, Kampala, Uganda \\ Patrick Byakagaba \\ School of Forestry, Environmental and Geographical Sciences, Makerere University, Kampala, Uganda \\ Aaron JM Russell \\ Center for International Forestry Research, Bogor, Indonesia \\ Daniel Waiswa \\ School of Forestry, Environmental and Geographical Sciences, Makerere University, Kampala, Uganda \\ Allan Bomuhangi \\ School of Forestry, Environmental and Geographical Sciences, Makerere University, Kampala, Uganda
}


Working Paper 157

๑ 2014 Center for International Forestry Research

(c) (1) Content in this publication is licensed under a Creative Commons Attribution 4.0 International (CC BY 4.0), http://creativecommons.org/licenses/by/4.0/

ISBN 978-602-1504-47-5

Banana AY, Byakagaba P, Russell AJM, Waiswa D and Bomuhangi A. 2014. A review of Uganda's national policies relevant to climate change adaptation and mitigation: Insights from Mount Elgon. Working Paper 157. Bogor, Indonesia: CIFOR.

Photo by Samuel R. Masaba

Landslide-prone slopes of Mt. Elgon, Bududa District, Uganda

CIFOR

Jl. CIFOR, Situ Gede

Bogor Barat 16115

Indonesia

$\mathrm{T}+62(251) 8622-622$

$\mathrm{F}+62(251) 8622-100$

E cifor@cgiar.org

\section{cifor.org}

We would like to thank all donors who supported this research through their contributions to the CGIAR Fund. For a list of Fund donors please see: https://www.cgiarfund.org/FundDonors

Any views expressed in this publication are those of the authors. They do not necessarily represent the views of CIFOR, the editors, the authors' institutions, the financial sponsors or the reviewers. 


\section{Table of contents}

Abbreviations $\quad$ v

Acknowledgments $\quad$ vi

Executive summary $\quad$ vii

1 Introduction 1

1.1 Project context 1

1.2 Methodology 1

2 Overview of forest and tree cover change in Uganda 3

2.1 Distribution of forested land among forms of ownership and management 3

2.2 Status of forest cover in Mount Elgon, Uganda 3

2.3 Impact of forest cover change on the environment and local livelihoods 4

2.4 The social political economy of deforestation and degradation in Uganda 5

3 Key policy changes affecting forest governance in Uganda 10

3.1 Pre-colonial forest resource governance in Uganda (up to 1900) 10

3.2 The colonial local forest reserves period (1900-1962) 10

3.3 Centralization of forest management following independence (1967-1992) 11

3.4 Decentralization of forest management and government (1993-present) 11

3.5 Forest governance in Uganda today 12

4 Climate change adaptation and mitigation policy regime in Uganda 15

$\begin{array}{ll}4.1 \text { Overview of the primary policies affecting vulnerability } & 15\end{array}$

5 Interaction of policies and their impacts in Mount Elgon 21

$\begin{array}{lll}5.1 \text { Current policy implementation on Mount Elgon } & 21\end{array}$

5.2 District-stakeholder priorities for achieving adaptation and mitigation objectives 22

6 Proposed policy implementation pathway 23

7 Conclusions and recommendations $\quad 24$

8 References 25

Appendix

$1 \quad$ Strategies for addressing climate change $\quad 28$ 


\section{List of figures and tables}

Figures

1 Land cover of Uganda, $2009 \quad 2$

2 Policy implementation pathway 23

\section{Tables}

1 Distribution of forested land by form of ownership and management 4

2 Forest cover change in Uganda, 1990-2005 4

3 Thematic priority areas for investment in Uganda's NAPA 19

4 NAPA priority projects for Uganda 19

5 Summary of the national policy and related climate change component 20 


\section{Abbreviations}

$\begin{array}{ll}\text { CBD } & \text { Convention on Biological Diversity } \\ \text { CDM } & \text { clean development mechanism } \\ \text { CFM } & \text { collaborative forest management } \\ \text { CIFOR } & \text { Center for International Forestry Research } \\ \text { DPM } & \text { disaster preparedness and management policy } \\ \text { DSIP } & \text { agriculture sector development strategy and investment plan } \\ \text { ECOTRUST } & \text { Environment Conservation Trust of Uganda } \\ \text { FAO } & \text { Food and Agriculture Organization of the United Nations } \\ \text { FLEGT } & \text { Forest Law Enforcement, Governance and Trade } \\ \text { GoU } & \text { Government of Uganda } \\ \text { IDP } & \text { internally displaced persons } \\ \text { IUCN } & \text { International Union for Conservation of Nature } \\ \text { KEFRI } & \text { Kenya Forestry Research Institute } \\ \text { NAADS } & \text { National Agricultural Advisory Services } \\ \text { NAPA } & \text { National Adaptation Program of Action } \\ \text { NEMA } & \text { National Environment Management Authority } \\ \text { NDP } & \text { national development plan } \\ \text { NFA } & \text { National Forestry Authority } \\ \text { PES } & \text { payments for ecosystem services } \\ \text { REDD } & \text { Reducing Emissions from Deforestation and Forest Degradation } \\ \text { UBOS } & \text { Uganda Bureau of Statistics } \\ \text { UNDP } & \text { United Nations Development Programme } \\ \text { UNFCCC } & \text { United Nations Framework Convention on Climate Change } \\ \text { UWA } & \text { Uganda Wildlife Authority } \\ & \end{array}$




\section{Acknowledgments}

This review was completed as part of a broader project, Adaptation of people to climate change in East Africa: Ecosystem services, risk reduction and human well-being. The Center for International Forestry Research (CIFOR) is leading the project in collaboration with Makerere University, the Kenya Forestry Research Institute (KEFRI) and the World Agroforestry Centre (ICRAF). The Faculty of Forestry at Makerere University is the primary implementing partner of the Ugandan research component. Primary funding for this project was provided through a grant from the Rockefeller Foundation (2011 CRD 306). Additional complementary funding for stakeholder workshops was received from two CIFOR-led projects funded by AusAID (63560) and UNITAR (G.EGP.2011.03).
The team would like to thank the village and district stakeholders from Bududa and Kapchorwa Districts and national stakeholders who have shared their knowledge, time and good will with us in the course of this research.

The authors would also like to thank two reviewers (Kaisa Korhonen-Kurki and Grace Wong) for their comments on a prior draft of this paper. Many other individuals at CIFOR and Makerere have contributed in making this research possible, including the administrative and research staff of the School of Forestry, Environmental and Geographical Sciences at Makerere University, CIFOR Library (searching/ sourcing literature), CIFOR ICG team (editing and layout of the working paper), and a range of staff in the Governance, Livelihoods, Finance, Administration, Human Resources, and the Nairobi Hub Offices. 


\section{Executive summary}

Climate change is expected to bring new challenges and possible opportunities for the livelihoods of rural communities in Uganda, where more than $80 \%$ of the population depends on rain-fed agriculture. The purpose of this review is to analyze the national policies on climate change adaptation, agriculture, forests, that guide management of forested and agroforested landscape ecosystems and their goods and services, and the roles of stakeholders in the national policy arena.

This review was conducted to provide the policy context for the project, Adaptation of people to climate change in East Africa: Ecosystem services, risk reduction and human wellbeing, which is underway in the Ugandan and Kenyan districts surrounding Mount Elgon. This is a collaborative project between the Center for International Forestry Research, Uganda Forestry Resources and Institutions Center, the Kenya Forestry Research Institute and the World Agroforestry Centre; it is funded by the Rockefeller Foundation.

This report begins with an overview of forest cover trends and the institutional and socioeconomic drivers of forest cover change in Uganda, with special attention to the region around Mount Elgon. It continues with an overview of the transitions in national forest governance paradigms since pre-colonial times and then reviews the range of national policies impacting on stakeholder efforts at climate change adaptation and mitigation. This is followed by a short overview of the activities being undertaken on Mt. Elgon under these policies, the district-stakeholder workshop recommendations for interventions that are needed, and an exploration of science-policy impact pathways. We conclude with the areas requiring action by researchers and policy makers alike.

The analysis reveals that nationally, deforestation has occurred primarily in non-protected areas, especially in savanna woodlands, with both local and global drivers. Forest governance of protected areas has been shifted from central authorities managing forests as central forest reserves, to local authorities managing forests as local forest reserves. However, the bulk of Uganda's forests are on land under private ownership. The Land Act (1998), National Forestry and Tree Planting Act (2003) and other national laws and international conventions ratified by Uganda offer a legal frameworks under which different types of forests are be managed and owned.

In addition, a range of natural resource policies have significant impacts enabling (or unintentionally limiting) the adaptation of stakeholders and ecosystems to climate change and/or contributing to increasing national carbon sequestration levels. These include the national environment policy (1995), national energy policy (2002), agriculture sector development strategy and investment plan (2010), national land use policy (2007), Uganda forest policy (2001), national water policy (1997) and national policy for the conservation and management of wetland resources (1994).

A draft climate change policy (2012) is awaiting cabinet approval. The Ministry of Water and Environment through its climate change unit is the focal institution and is responsible for coordinating the country's responses to climate change issues. The draft policy suggests that policy responses, either sector specific or crosscutting in nature, should be harmonized in order to better address the challenges associated with climate change adaptation and mitigation.

Based on this analysis of the policies that affect ecosystem services provision and livelihoods, stakeholders identified the forest, wildlife and agriculture policies as the policies, and their respective programs as having the most significant impacts on forests, ecosystem services, livelihoods, and climate change adaptation or mitigation objective in the Mount Elgon area. As lessons to be learned for development of climate change adaptation and mitigation policies, it has become apparent that most national policies are developed with limited local engagement, resulting in limiting options for local and district-level stakeholders to achieve the intended objectives. Additionally, the contradictions between the activities promoted by different ministries remain a significant challenge undermining the effectiveness of each respective policy. As the climate change coordinating 
institution, the Ministry of Water and Environment will have to address these same issues to ensure that all ministries are cooperating in contributing to the overall objective of increasing adaptive capacity to climate change and increasing carbon sequestration.
Clearly, climate change adaptation and mitigation requires a landscape approach that encompasses and integrates interventions from forestry, agriculture, wildlife, and many other sectors, rather than allowing them to persist in their separate silos. 


\section{Introduction}

\subsection{Project context}

The Fifth Assessment Report of the Intergovernmental Panel on Climate Change (IPCC 2014) anticipates rapid changes in climate, even if greenhouse gas emissions are reduced quickly. Mitigation efforts can lessen, but not prevent, future climate change. The majority (80\%) of Uganda's population is reliant on rain-fed agricultural activities to provide the majority of its food and significant proportions of its income requirements (UBOS 2007). Consequently, any changes in climate, in terms of overall temperature and precipitation levels, or in terms of changes in seasonality of rainfall will have significant and widespread impacts on livelihoods and on the ecosystem services that they rely upon. Anticipating and adapting to these impacts in order to minimize their human and environmental consequences are major challenges. Adaptation is frequently presented as a process or set of processes designed to reduce vulnerability and to minimize the potential negative impacts of variable climate stimuli (Adger et al. 2007). Forests are a critical source of ecosystem services, which underpin the livelihoods as well as the having impacts on the sensitivity and adaptive capacities of many economic sectors at local, national, regional and global scales (Russell et al. 2013). Continued forest degradation and loss in Uganda have a significant negative impact on people's livelihoods and the provision of ecosystem services.

Over the years, Uganda has undergone several policy and legal reforms to ensure sustainable management of its forests. A major challenge faced by governments and policy makers in Uganda and other countries in the region is reducing the vulnerability of people and climate-sensitive sectors, including water, agriculture and energy, to climate variability, and ensuring that future development activities are appropriate to future climate contexts. The present policy review is part of a research project, Adaptation of people to climate change in East Africa: Ecosystem services, risk reduction and human well-being, funded by the Rockefeller Foundation. The project aims at understanding how climate change will affect the resilience of agriculture-based livelihoods and natural resource management regimes in East Africa.
The overall objective of the project is:

To contribute to the development of local plans and national policies for adaptation to climate change, with emphasis on forest and tree ecosystem services as a central component of risk reduction, poverty alleviation, human well-being, and synergies with climate change mitigation

(AdaptEA project proposal)

The specific objectives are as follows:

- Analyze national policies on climate change adaptation, forest and agroforestry management, and forest and agroforestry goods and services and the roles of stakeholders in the national arena.

- Assess the current and future vulnerability of agricultural livelihoods in selected sites, with a focus on land and natural resources management institutions, and how the ecosystem goods and services provided by forests and trees help reduce vulnerability.

- Assess the current and future roles of ecosystem regulating services (e.g. hydrology, microclimates) of forests and trees in enhancing the resilience of agricultural production.

- Develop, assess and communicate ecosystembased approaches to adaptation (including the synergies between adaptation and mitigation) in local initiatives and national policies.

In this report, we specifically seek to "analyze national policies on agriculture, forestry, management of forested and agro-forested landscape ecosystem goods and services as they relate to climate change adaptation and the roles of stakeholders in the national arena".

\subsection{Methodology}

A two-step approach was used to investigate the impact of climate change related policies on climate change adaptation and mitigation in the Mount Elgon region. In the first phase, deductive qualitative content analysis (Mayring 2000) of policies, legislation and peer-reviewed articles in scientific journals was carried out. Deductive 


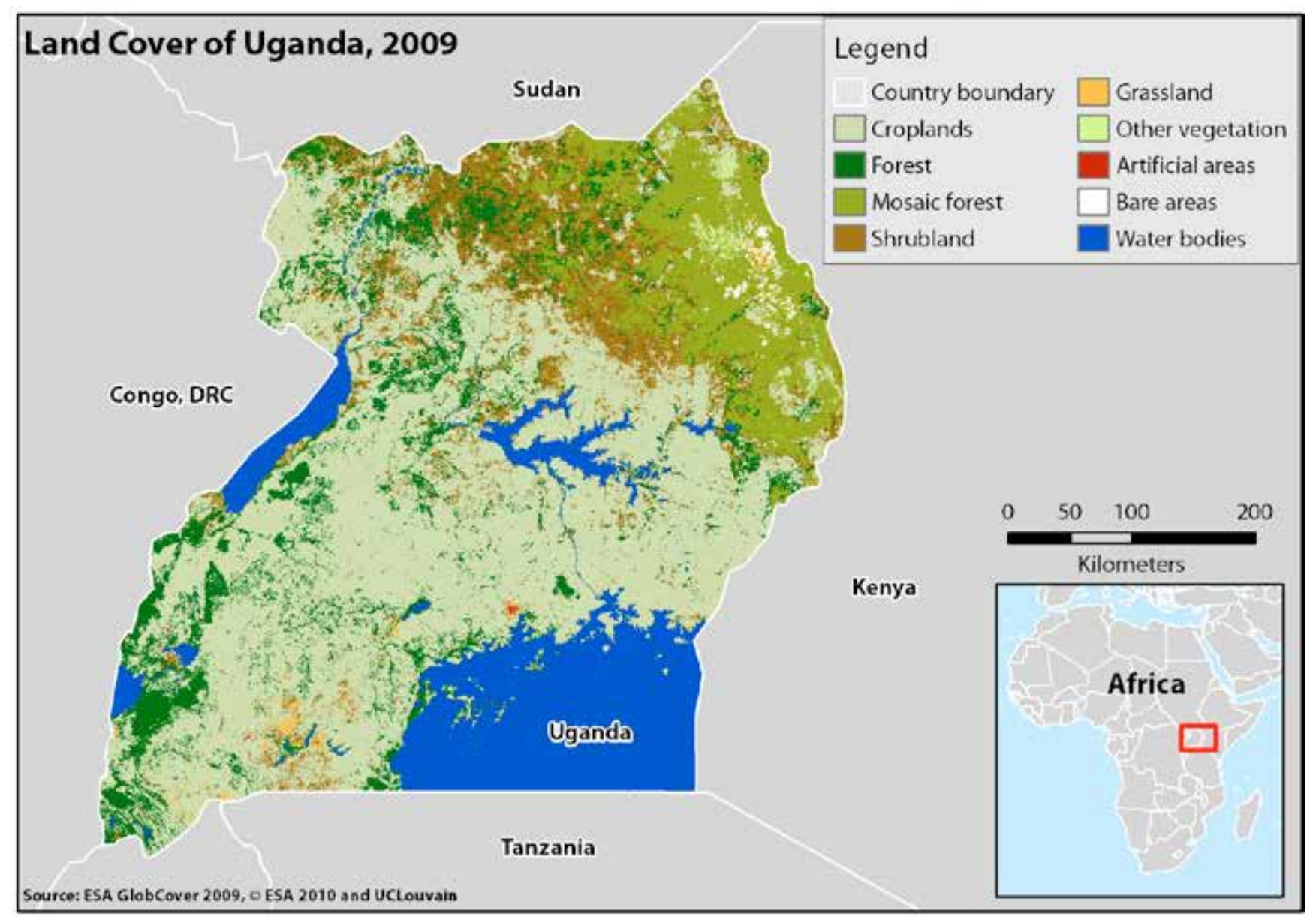

Figure 1. Land cover of Uganda, 2009

category application works with prior formulated, theoretical derived aspects of analysis, bringing them in connection with the text. In the second phase, the rapid rural appraisal approach was used (Chambers 1992) to seek the views of the stakeholder inputs during a vulnerability scoping analysis workshop. Two district and two village stakeholder workshops were held with men, women and youth in Kapchorwa and Bududa districts. Stakeholder inputs were critical for assessing the impacts of policies on both the key community livelihood activities around Mount Elgon and their dependence on ecosystem services. 


\section{Overview of forest and tree cover change in Uganda}

\subsection{Distribution of forested land among forms of ownership and management}

At the beginning of the 19th century, forests and woodlands covered approximately $45 \%$ of the total land area of Uganda (Obua et al. 2010). The colonial government in Uganda established a comprehensive network of protected areas at the beginning of the 20th century to ensure a sustainable supply of economic, social and environmental services from forest resources. However, the bulk of Uganda's forests $(70 \%)$ are on privately owned land and customary land, with the remaining 30\% in the protected area network, such as national parks or forest reserves (Table 1).

Forest cover has been reduced to 4.9 million ha, or about $20 \%$ of the total land area. About $30 \%$ of the tropical high forests are degraded. The overall rate of deforestation in Uganda is estimated to be $2.4 \%$ per year (FAO 2007). According to the National Forestry Authority (NFA 2005), the rate of deforestation is low (less than 1\%) in the well-stocked tropical high forests. These forests are predominantly in national parks, where the Uganda Wildlife Authority (UWA), together with the resource use and boundary management village committees under collaborative resource management arrangements, monitor and enforce park rules. Collaborative resource management has proved successful in some forested national parks (Table 2).

The rate of deforestation is estimated to be $2 \%$ in the low-stocked tropical high forests (NFA 2005). These forests are predominantly on private lands, in forest reserves and on customary land in central Uganda within the fringes of the Lake Victoria crescent. This region of Uganda has a long history of human occupancy, cultivation and fire, which is used to maintain grazing lands (Banana et al. 2010).

In the recent past, the deforestation rate has been highest in the savannah Acacia woodlands ecosystem of central and northern Uganda. Between 1990 and 2005, the rate of deforestation was estimated to be $3.85 \%$ (FAO 2007). Most of the forests in this ecosystem are outside gazetted forest reserves, being on customary land in northern Uganda or on private land in the cattle corridor of central Uganda. Better economic returns accrue from alternative land uses, such as charcoal production, cattlefarming, subsistence agriculture and commercial ranching (Namaalwa et al. 2001).

\subsection{Status of forest cover in Mount Elgon, Uganda}

The forest in Mount Elgon National Park covers $1145 \mathrm{~km}^{2}$ and is an important water catchment area for millions of people in Uganda, Kenya and other countries in the Nile Basin (Van Heist 1994). The mountain is the source of several rivers, including River Manafa and River Sironko, which are major tributaries of the River Nile.

As a result of altitudinal changes, four vegetation zones or ecosystems are found on the slopes of Mount Elgon. These ecosystems are:

- the lower slopes (below $2000 \mathrm{~m}$ above sea level), which were formerly open woodlands but are now intensively cultivated

- the Afro-montane moist forest located on the mid-slopes (2000-2500 m above sea level)

- the bamboo zone (2500-3000 $\mathrm{m}$ above sea level)

- the Afro-alpine zone above the bamboo zone. Moorlands, swamps and rocks form a major part of the Afro-alpine zone.

The Afro-montane moist forest located on the mid-slopes (2000-2500 m above sea level) now a national park - was previously dominated by Juniperus procera, Hagenia abyssinica, Olea welwitschii, O. hochstetteri, Prunus africana, Podocarpus falcatus and Podocarpus latifolius tree species. Most of these species were overharvested before the forest was gazetted as a national park (UFRIC 2008). The forest was restocked with indigenous species during the 1990s, as part of the FACE project.

The Kapkwai forest patch in Mount Elgon National Park, located in Kapchorwa district, has been rapidly recovering since the national park was established, 
Table 1. Distribution of forested land by form of ownership and management

\begin{tabular}{lcccr}
\hline \multirow{2}{*}{ Land cover } & \multicolumn{2}{c}{ Government } & Private/ customary tenure & Total \\
\cline { 2 - 4 } & $\begin{array}{c}\text { Forest reserve } \\
\text { (NFA) }\end{array}$ & $\begin{array}{c}\text { National park } \\
\text { (UWA) }\end{array}$ & Private & 924,000 \\
\hline Tropical high forest & 306,000 & 267,000 & 351,000 & $3,975,000$ \\
Woodlands & 411,000 & 462,000 & $3,102,000$ & 33,000 \\
Plantation & 20,000 & 20,000 & 11,000 & $4,932,000$ \\
Total forest & 737,000 & 731,000 & $3,464,000$ & 24.16 \\
\% Forest cover (\%) & 64.03 & 38.51 & 19.95 & $15,482,000$ \\
Other cover types & 414,000 & $1,167,000$ & $13,901,000$ & $20,414,000$ \\
Total land & $1,151,000$ & $1,898,000$ & $17,365,000$ & 100.00 \\
\% of national "forested land" (\%) & 5.64 & 9.30 & 85.06 & 70.24 \\
\% of national forest cover (\%) & 14.94 & 14.82 & & 100.00 \\
\hline
\end{tabular}

Source: GoU (2001)

Table 2. Forest cover change in Uganda, 1990-2005

\begin{tabular}{lrrrc}
\hline Forest area (ha) & \multicolumn{1}{l}{} & \\
\hline Forest type & 1990 & 2005 & Change in area & Annual change (\%) \\
\hline Broad-leaved & 18,682 & 9,915 & $-8,767$ & -2.9 \\
Needle-leaved & 16,384 & 15,535 & -849 & -0.3 \\
Tropical high forest - well stocked & 651,110 & 580,010 & $-71,100$ & -0.7 \\
Tropical high forest - low stocked & 273,061 & 187,147 & $-85,914$ & -2 \\
Woodlands & $3,974,508$ & $1,679,558$ & $-2,294,950$ & -3.6 \\
\hline
\end{tabular}

Source: MWE (2011)

possibly because of better collaboration between the local communities and park management. The dominant trees in Kapkwai forest are Neobutonia macrocalyx (10 trees/ha), Xymalos monospora (6 trees/ha) and Acacia senegalensis (3 trees/ha) (UFRIC 2008).

By contrast, the Bufuma forest patch in Bududa district remains in a degraded state. This forest patch, too, was previously dominated by Juniperus procera, Hagenia abyssinica, Olea welwitschii, O. hochstetteri, Prunus africana, Podocarpus falcatus and Podocarpus latifolius tree species (UFRIC 2008). At present, it is dominated by Draceana fragrans, Macaranga monandra, Dombeya sp., Maesa lanceolata and Podocarpus milianjanus.

This patch of forest on Mount Elgon remains degraded, despite the establishment of the national park, because illegal cultivation and unsustainable harvesting of fuelwood, charcoal, timber and construction materials, bamboo shoots, fodder and other non-timber forest products have increased dramatically, possibly for the following reasons:

- the collaborative resource and boundary management committees in Bududa are not functioning, which is attributed to poor collaboration between the local communities and park management

- $\quad$ high population pressure in the area

- low productivity of farming systems, leading to a decline in the contribution of agriculture to household income.

\subsection{Impact of forest cover change on the environment and local livelihoods}

Most households in the tall grasslands agroecological zone, where tropical high forests are located, maintain agroforestry subsistence farming systems dominated by a banana-coffee-fruit tree matrix 
(Vogt et al. 2006). Farmers grow a mix of crops including perennials (e.g. banana and coffee), annuals (e.g. maize, beans, vegetables, etc.), trees (e.g. Artocarpus heterophyllus, Mangifera indica, Ficus natalensis, Maesopsis eminii and Eucalyptus saligna) and fodder grasses (e.g. Pennisetum purpureum). Trees are grown in the valleys and on the mid-slopes for provision of fuelwood, fruits, windbreaks, shade, erosion control and soil fertility. These on-farm tree resources are increasingly becoming the main goods and services that local people depend on for their livelihoods because of the decline in natural forest cover.

In the short grass agroecological zone, where woodlands are located, the farming system is dominated by the Shea tree (Vitellaria paradoxa) and Combretum collinum. The Shea tree is important because of the oil processed from its nuts. Most of the charcoal used in major urban centers in Uganda is obtained from this agroecological zone. Consequently, most largestemmed trees in this zone, including the Shea tree, are under pressure, mainly because of the reduced density of both juvenile and mature trees due to agricultural expansion and charcoal production (Byakagaba et al. 2011).

In addition, most national parks in Uganda encompass wooded savannas and tropical moist forests. Degradation of these ecosystems would lead to huge losses of revenue from the tourism industry.

Montane forests on Mount Elgon have been reported to be the regional centers of endemism in Uganda (Plumptre et al. 2003). Large portions of Mount Elgon were formally declared to be a forest reserve in 1951 and as a national park in 1992. Despite the high conservation status of this ecosystem, local communities depend on it for the provision of goods and services such as timber, fuelwood and poles for building.

The formerly open woodlands on the lower slopes have been intensively cultivated because of the presence of fertile volcanic soils that support intensive farming activities. The communities have replaced the indigenous tree species with eucalypts, especially Eucalyptus grandis for a supply of poles and fuelwood, and a variety of fruit trees. Only a few indigenous tree species now grow there. Arabica coffee, beans, vegetables and bananas are the main agricultural crops grown in this ecosystem.
The local communities around Mount Elgon depend heavily on the bamboo zone for food, poles and fuelwood. National park rules allow communities to harvest young bamboo shoots for food, and dry bamboo for fuelwood and poles.

There is no doubt that the ongoing degradation of forest resources in Uganda in general and in the Mount Elgon region in particular is increasing the vulnerability of local communities to climate change. The main impacts of climate change are envisaged to affect food security through more droughts, scarcity of water resources and loss of biodiversity. In the Mount Elgon region, it is envisaged that heavier rainfall in the mid- and high-altitude zones of the mountain will lead to frequent floods, landslides, more soil erosion and land degradation (IPCC 2014).

\subsection{The social political economy of deforestation and degradation in Uganda}

The drivers for forest and tree cover change were assessed following a framework developed by Jomo et al. (2004). This framework describes the political economy of the root causes of deforestation and degradation and gives an indication of the opportunities and constraints of the national REDD policies. For this study, the root causes of deforestation and degradation largely defined here as forest and tree cover change were related to climate change related policies for Uganda.

\subsubsection{Socioeconomic factors}

Globally, socioeconomic factors contribute to alter or deplete the forest cover and affect forest structure and species composition (Schwartz and Caro 2003). Population growth is undoubtedly one of the most critical socioeconomic factors that could alter the pattern of forest resource use. In Uganda, about 2.7 million people ( $15 \%$ of Uganda's population) were estimated to live in parishes that neighbor tropical high forests in 1999 (Jacovelli and Caevalho 1999). It is possible that this number may have since doubled, thus settlements and population growths are major drivers of deforestation in this ecosystem.

Degradation in the savanna woodlands is caused by better economic returns for alternative land uses such as charcoal production, cattle farming, subsistence agriculture and commercial ranching (Banana et al. 2010). Thus, the main drivers of deforestation 
in this ecosystem are the greater profitability of alternative land uses such as plantations, tourism, traditional cattle-farming and ranching, and the heavy dependence on charcoal and fuelwood because of a lack of alternative energy sources.

\subsubsection{Land tenure}

Most of the degraded forest resources in Uganda are on private land under the different land tenure systems provided for in the Constitution and the Land Act, 1998 of Uganda. High numbers of privately owned forests have been converted to agricultural land. Nearly 1.3 million ha of forests located outside protected areas (private and community forests) have been lost over the past 15 years (Becker et al. 1995; Banana et al. 2007). This indicates that land tenure and property rights have a substantial influence over changes in forest cover. Private landowners have few incentives to keep their land under forest cover. Often, alternative land uses, such as subsistence and commercial agriculture and livestock keeping, are more profitable than keeping the land under forest (Namaalwa et al. 2001).

The lack of clearly defined and enforceable property rights in most of the country's forests has created a de facto open access situation, which is one of the main causes of deforestation. This is especially common where forests are found on customary land in areas where the traditional governance structure has broken down (Gombya-Ssembajjwe 1995).

\subsubsection{Lack of political commitment and poor governance}

A number of key institutional weaknesses limit government's ability to address the drivers of deforestation.

Illegal logging and encroachment on forested lands are fueled by political interference, corruption, political patronage, political interference and lack of commitment to use best forest management practices (Banana et al. 2010). The result is weak governance and forest law enforcement, and hence non-collection of revenue, deforestation and forest degradation. According to Transparency International's 2005 and 2009 Corruption Perception Indexes, Uganda scored less than 3 out of a possible score of 10 , indicating very serious levels of corruption (Transparency International 2009).

Conflicting government policies, coupled with poor implementation of policies has resulted in poor governance of natural resources. The recent degazettement of forest reserves for the establishment of large-scale agricultural and forest plantations, industrial parks and urban centers is an example of conflicts between government policies (Obua et al. 2010).

Weak governance and political weakness have also led to frequent civil wars in Uganda, which significantly affects land use and land-cover changes. For example, central and northern Uganda were at war during 1980-1986 and 1986-2005, respectively, when the communities in these areas lived in internally displaced persons' (IDP) camps. Landsat images from the mid-1980s show that the movement of large numbers of people - up to 1.5 million - to IDP camps enabled the vegetation to recover, but led to the degradation of vegetation around the camps and urban centers where they were resettled (Nampindo et al. 2005).

\subsubsection{Policies outside the forestry sector affecting land cover change in Uganda} Uganda's energy policy has a significant impact on land use and forest cover change in Uganda. The high taxes on alternative energy sources (notably electricity and fossil fuels) have led people to continue to use fuelwood for household and commercial uses $(\mathrm{GoU}$ 2009). It is estimated that more than $85 \%$ of the energy in Uganda is generated from biomass derived mainly from forests. The forests on private land are the most susceptible to degradation from biomass energy producers.

In 2005, an executive order (presidential directive) banning the eviction of encroachers from central forest reserves (forests under the NFA) was made, and this ban remains in force. This has undermined efforts to control the presence of encroachers in these reserves (White and Byakagaba 2010). In 2011, another executive order banning the NFA from leasing central reserves that were gazetted for tree plantations to private planters was made. This order has had the effects of slowing reforestation programs for reserves and making these reserves more susceptible to encroachment.

\subsubsection{Structural adjustment programs (SAPs)}

In the 1990s, Uganda implemented a structural adjustment program in a bid to qualify for International Monetary Fund and World Bank loans. One of the reforms, privatization and economic liberalization, led to higher prices for agricultural 
crops (Vogt et al. 2006; Banana et al. 2007) and greater incentives to expand the production of export commodity crops, which encouraged landowners to convert their forests to agricultural uses. It is estimated that about 20,000 ha of natural tropical high forested land has been allocated to oil palm and sugarcane plantations in central Uganda (Banana et al. 2010). Forested land under government stewardship is usually the first candidate for conversion to agricultural land uses as an incentive for large-scale agricultural investors.

In contrast, trees on farm have become an important source of livelihoods for local people, and the number of trees on-farm has significantly increased since the privatization and liberalization policies were launched.

\subsubsection{Regional and global forest-related processes affecting forest cover change in Uganda}

Several regional and/or global forest-related processes are underway in Uganda that have an impact on land use and forest cover change. Uganda signed the Lusaka Agreement on Cooperative Enforcement Operations Directed at Illegal Trade in Wild Flora and Fauna in 1994. This agreement was signed by countries in Eastern, Central and Southern Africa, who agreed to work together to stop the illegal trade in wild flora and fauna. It aims to reduce and gradually eliminate this illegal trade by creating a task force responsible for implementing it. It is derived from the Convention on Biological Diversity (CBD) and the Convention on International Trade in Endangered Species of Wild Fauna and Flora (CITES). Forests are indirectly protected by this agreement because most flora and fauna are found in forest habitats.

Uganda is party to the treaty of the East African Community of 1999, which has as one of its objectives, the sustainable use of natural resources of partner states. Article 111 of this treaty provides for the sustainable management of environment and natural resources including, but not limited to, forests. Partner states "agree to take concerted measures to foster cooperation in the joint and efficient management and sustainable utilization of natural resources within the community" and commit to "adopt common regulations for the protection of shared aquatic and terrestrial resources" (Article 114). Uganda thus has a legal obligation, arising from its membership of the East African
Community, to manage its natural resources, such as forests, sustainably.

Uganda is also a signatory to the East African Community Memorandum of Understanding on the Environment, which provides for the development of harmonized national and sectoral mechanisms for the management of the shared resources of transboundary resources and ecosystems, especially forests, wildlife and water. This framework has enabled the implementation of joint management initiatives among institutions and departments required to manage forest resources that cross national boundaries. Similarly, Uganda is a signatory to the Common Market for Eastern and Southern Africa Treaty, signatories to which commit to ensuring prudent and rational use of natural resources such as forests.

The Mount Elgon Regional Ecosystem Conservation Programme (MERECP) is one of these transboundary initiatives. It is a natural resource management program run by the East African Community, a grouping of Kenya, Uganda, Tanzania, Burundi and Rwanda. Its aim is to secure the multifunctionality of Mount Elgon and enhance its sustainable development. According to Muhweezi et al. (2007), this program has enabled collaboration between implementing institutions, especially through sharing information, joint planning and patrolling of protected areas. However, in their study, Petursson et al. (2011) reported that the process that MERECP followed was top-down, involving only politicians who lived far away from the local communities, which would make the objectives difficult to achieve. They further argued that if deforestation is to be addressed in this ecosystem, institutional-level constraints must be addressed.

The International Gorilla Conservation Programme, run by protected area authorities in Uganda, Rwanda and the Democratic Republic of Congo in the Virunga and Bwindi Forest ecosystem is the other regional trans-boundary initiative. The program was launched in 1997 as a joint initiative aimed at addressing illegal activities and joint monitoring of the flora and fauna in this ecosystem. Through the program, authorities receive information that can help them address the threats to this ecosystem (Gray and Kalpers 2005).

Uganda is also a party to the Convention on International Trade in Endangered Species of Wild 
Fauna and Flora (CITES), which aims to ensure that international trade in wild animals and plants does not threaten their survival. This is envisaged to be achieved through appropriate trade control measures and monitoring of the status of endangered species. Uganda represents the Eastern Africa region on the standing committee, a position that further galvanizes its obligation to ensure that trade in endangered species of wild fauna and flora is regulated.

The species covered by CITES are listed in three appendixes according to the degree of protection they need. Appendix I includes species threatened with extinction; trade in specimens of these species is permitted only in exceptional circumstances. Appendix II includes species not threatened with extinction, but in which trade must be controlled in order to avoid use incompatible with their survival. Appendix III contains species that are protected in at least one country. Uganda has listed 10 species of animals and 7 species of plants in Appendix I, and 167 species of animals and 91 species of plants in Appendix II. One species of animals is considered in Appendix III (http:// www.cites.org/eng/resources/species.html). This has buttressed conservation efforts geared toward sustaining forests where most of the flora and fauna listed in these appendices are found (Winterbottom and Eilu 2006).

Uganda signed the River Nile Cooperative Framework Agreement (CFA) in May 2010 under the auspices of the Nile Basin Initiative, whose mission is "to achieve sustainable socio-economic development through the equitable utilization of, and benefit from, the common Nile Basin water resources" (http://www.nilebasin.org/newsite).

Principle 7 of the agreement states that "Nile Basin States will take all appropriate measures, individually and, where appropriate, jointly, for the protection and conservation of the Nile River Basin and its ecosystems". Article 6 of the agreement requires States that are party to this agreement, "to protect, conserve and, where necessary, rehabilitate the Nile River Basin and its ecosystems, in particular, by: (a) protecting and improving water quality within the Nile River Basin, ...(c) protecting and conserving biological diversity within the Nile River Basin; (d) protecting and conserving wetlands within the Nile River Basin; and (e) restoring and rehabilitating the degraded natural resource base". Forests around the Nile Basin in Uganda attained more protection through this agreement because Article 5 of the agreement requires Nile Basin States to take all appropriate measures to prevent significant harm to other Basin States. Activities that can reduce the cover of the forests in water catchments, which are critical for the sustainability of the river, are considered unacceptable in this agreement.

Global forest-related processes that are underway in Uganda and that have an impact on land use and forest cover change include the clean development mechanism (CDM), payments for ecosystem services (PES) (also known as payments for environmental services), Reducing Emissions from Deforestation and Forest Degradation (REDD) and the Forest Law Enforcement, Governance and Trade (FLEGT) Support Programme for African, Caribbean and Pacific countries (ACP-FLEGT Support Programme). These all influence the domestic policy environment and the behavior of actors in the forestry sector (Banana et al. 2013). For example, more civil society organizations can hold government institutions accountable when forest rules and regulations are violated. A climate change unit in the Ministry of Water and Environment, a REDD focal point and REDD working group have been established to stimulate policy discussions on measures that might contribute to the mitigation of climate change, including sustainable forest management.

Although there are no well-established guidelines for PES in Uganda, examples of some initiatives include the following:

- UWA FACE project in Mount Elgon and Kibale National Parks

- Nile Basin CDM project of Rwoho Central Forest Reserve

- ECOTRUST Trees for Global Benefits Program (nationwide).

These initiatives have been important in raising awareness about the importance of trees and forests among the communities in which the programs are underway.

Uganda is a signatory to various other international conventions governing the management of forest resources, including the Convention on Biological Diversity, the Rio Declaration, the Convention on International Trade in Endangered Species of Flora and Fauna, the United Nations Framework Convention on Climate Change (UNFCCC), the 
Convention to Combat Desertification, Kyoto Protocol, Common Market for Eastern and Southern Africa Treaty and the East Africa Treaty. All these agreements either directly or indirectly require Uganda to make regulations that have an impact on land use and forest cover. The forestry policy of 2001 recognizes the importance of integrating various actors into the management of forests, such as local communities, private-sector actors and indigenous tribes. It also recognizes the important economic, social and environmental benefits that forests and trees bring to the people of Uganda. These elements of the policy were adopted from the Rio Declaration, which Uganda ratified.

As a signatory to the UNFCCC, Uganda has been a beneficiary of developed countries' interest in increasing carbon sequestration in developing countries through additional financial support for climate change mitigation.
As a signatory to the Kyoto Protocol, Uganda has registered a number of CDM projects, notably five Nile Basin reforestation projects, which were the first in Africa, and Kacung Afforestation and Reforestation Project. Having a regulated carbon market is recognized in both policies and plans as a strategic step for increasing the economic benefits derived from forests. A significant number of private forest owners are following the principles of CDM in managing their forests in anticipation of registering them for CDM markets. The five critical measures required of parties to the $\mathrm{CBD}$ are all enshrined in the forestry policy and Act and the environment policy; these include integrating sustainable use into national strategies and plans and programs, promoting in situ conservation, protecting traditional knowledge about conservation, protecting threatened species, promoting the sustainable use of biological diversity and promoting international cooperation in the protection of biological resources. 


\section{Key policy changes affecting forest governance in Uganda}

Forest management in Uganda has been decentralized and recentralized a number of times since independence in 1962. The changes often came as a result of policies adopted by different governments in the management of public affairs. Until the late 1990s, forest management in Uganda was mainly a public matter, more or less confined to forest reserves (FRs). Before 1967, there was a vibrant local government (LG) forestry service, which ran local forest reserves (LFRs), especially under the kingdoms that had built strong coherent government systems from the colonial days. At that time, LGs had powers to decide on development priorities for their areas. Nevertheless, the central government (CG) was still responsible for managing some of the forest reserves.

In 1967, the Ugandan government adopted a republican constitution, which centralized virtually all government decision-making powers. Consequently, all LFRs became central forest reserves (CFRs). In 1993, the government adopted the policy of decentralization. This also decentralized forest reserves. But it soon became clear that the LGs were not yet ready to take on forest management responsibilities fully. They needed revenue to run more urgent activities such as education, water and health, which had also been decentralized. So, they set about harvesting the forests with little consideration for their planned management.

In 1995, Uganda adopted a new constitution. This constitution embraced the 1993 decentralization policy fully, but it remained ambivalent about management of forests. The National Forestry and Tree Planting Act of 2003 maintained the 1998 state of affairs, but this time it created a semiautonomous National Forestry Authority (NFA) out of the FD. While the FD had been responsible for all aspects of forestry in the country, the NFA was created with the responsibility to manage CFRs only.

Public administration reforms made alongside these changes in forest policy also affected landtenure regimes.

\subsection{Pre-colonial forest resource governance in Uganda (up to 1900)}

Before the establishment of colonial rule in Uganda, rural communities had various customary rules to govern the use of forests. Use of forests was communal and management was based on cultural rules, or informal institutions that all members of the community had learned through their oral traditions. These informal institutions included penalties, sanctions and incentives to ensure that all members adhered to the socially acceptable use of the forests in their surroundings (Beyaraza 2004). During this period, certain tree species were given special protection because of their medicinal uses.

In some regions, especially Buganda and Bunyoro, certain forests were 'declared' as sacred and hence access to, and use of, such forests could only happen through a caretaker who was believed to have supernatural powers. Such forests were believed to be hosts of spirits that the communities would invoke for their personal and group prayers. Consumptive use was more or less forbidden unless it was authorized by the caretaker (GombyaSsembajjwe 1995). In areas with a centralized system of governance with kings and local chiefs, all forests were under the stewardship of these leaders, but ordinary people had user rights (GombyaSsembajjwe 1995).

\subsection{The colonial local forest reserves period (1900-1962)}

During the colonial period, all key forest reserves were registered and established as local forest reserves under the authority of the district administrations (a process extending from 1939 to 1947; Kamugisha 1993). The colonial government used command-and-control approaches, commonly referred to as the 'fortress' approach, in the management of forests. The traditional systems of forest management were replaced with 'modern' forest management systems in which forestry officers and chief conservators were given absolute authority to determine the use and management of forests. 
Local communities were deprived of their rights to access forest estates.

The early policies (forest policy of 1929, 1938) focused mainly on declaring forest estates as reserves and increasing economic efficiency in the management of forests under State control. The 1948 policy stressed the importance of integrating the central government and local governments (kingdoms) into managing forests. It was through the implementation of this policy that formal reservation of forests started. Reservation of forests had negative impacts on communities who depended on forests for their livelihoods. They were displaced without any compensation, and traditional institutions for forest management were greatly weakened (Kamugisha 1993; Turyahabwe and Banana 2008).

\subsection{Centralization of forest management following independence (1967-1992)}

In 1967, Uganda became a republic, and the 1969 Public Lands Act (Beyaraza 2004) and the Land Reform Decree of 1975 (Beyaraza 2004) authorized the central government to take over the management and use of resources on land, including forests. Similarly, the 1964 Forest Act and the forestry policy of 1970 gave the mandate of forest management and ownership to the central government through the Forest Department. This policy focused on exploiting the commercial value of forests, mainly for timber production. It did not adequately address conservation issues, and attention to conservation declined further with the economic and political distress under the regime of Idi Amin; this resulted in additional forest loss. During this period, many forests reserves, especially in central Uganda, were converted to cropland under the government policy of doubling agricultural production (Kamugisha 1993). Uganda was under economic sanctions at this time, and the ruling government thought it wise to increase production in order to sustain the economy.

The 1988 forestry policy included biodiversity conservation and an ecosystem-based approach to forest management. Yet, despite its interest in sustainable management of forests, the policy was silent on the involvement of local people in forest management and did not cover forests outside gazetted reserves (Turyahabwe et al. 2007). This led to loss of forests on private land and increased conflicts with communities adjacent to forest reserves. No new law was enacted to facilitate the implementation of this policy. By 1992, the Forest Act of 1947, amended in 1964, had become obsolete, given the new challenges and changes in the country's economic situation.

\subsection{Decentralization of forest management and government (1993- present)}

In 1993, the Government of Uganda initiated a process of devolving forest management authority of central forest reserves to district governments. The high rate of deforestation and the global paradigm shift on forest management following the Rio Declaration, which Uganda ratified, were cited as the major reasons for these governance reforms in the forest sector (Banana et al. 2007; Turyahabwe et al. 2007). To implement the new framework of managing forests, a new forest policy was formulated in 2001 to develop an integrated forest sector that could achieve sustainable increases in the economic, social and environmental benefits from forests and trees for all the people of Uganda, especially the poor and vulnerable. It recognized conservation, sustainable development and institutional reforms, such as collaborative forest management, as critical in forest management.

In 2003, the amended Forestry Act of 1964 was finally replaced by the National Forestry and Tree Planting Act of 2003 (GoU 2003). Under this Act, all forests in Uganda were reclassified as follows:

- central forest reserves (about 15\% of total forested land)

- forests under national parks (about $15 \%$ of total forested land)

- local forest reserves (less than $0.5 \%$ of total forested land)

- community forests (less than $0.5 \%$ of total forested land)

- $\quad$ private forests (70\% of total forested land).

Local forest reserves are governed by district governments and community forests are managed by registered community-based organizations, which are monitored by the district forest officer. These changes to the forestry policy and Forestry Acts were accompanied by similar changes in the Land Act (1998) and Land (Amendment) Act (2010), which had significant impacts on land-tenure security and incentives structuring behavior in relation to forest cover. 
The Land Act recognizes four tenure systems, as described by Uganda Land Alliance (1997):

- customary, whereby a system of land ownership is governed and regulated by customary principles and regulated and usually sanctioned by a customary authority; customary land tenure is the most widespread tenure type in Uganda

- freehold, whereby the government grants someone perpetual and full ownership

- leasehold, whereby the government grants someone the right to exclusive possession of land for a specified period, usually although not necessarily, in return for a periodic payment of rent

- mailo ${ }^{1}$ This system was introduced as a result of the 1900 Buganda Agreement, which divided the land in Buganda between the kabaka (king), his chiefs and the colonial government. It is similar to freehold in that it entails holding registered land in perpetuity, but it is subject to customary and statutory rights of lawful and bona fide occupants.

Although these acts have improved land and tree tenure security for rural people, their impacts on tree/forest cover are mixed. Before the new Act, landlords in the mailo system could prohibit tenants from planting trees of commercial value except fruit trees. Under the new Land Act of 1998 (GoU 1998), landlords cannot evict tenants without compensation for all the developments the tenants have made on the land, including tree crops. Hence, tenants had a strong incentive to plant trees on their farms following the reform of land tenure regimes because of improvement in land and treetenure security. At the same time, however, tenure security has contributed to recent unprecedented deforestation on private land. Whereas previously, landowners were restricted in their right to deforest their land by the Land Act 1969, which authorized forest officers to regulate tree harvesting, the current Land Act does not.

Although the Forestry and Tree Planting Act of 2003 requires private forest owners to manage and use their forests sustainably, it does not set out sanctions or penalties for those who fail to comply with the management rules for forests on private

\footnotetext{
1 A quasi freehold land tenure system that is subject to the statutory and customary rights of lawful and bona fide occupants.
}

land, and consequently does not prevent them from converting the forests to other land uses.

The target in the national development plan is to increase the permanent forest cover in Uganda from the current estimate of $14 \%$ (Obua et al. 2010) to $24 \%$ (including natural and planted forests) by 2015 (GoU 2010b). The policy recognizes agricultural expansion as a threat to forest cover, but it is silent on strategies to address it.

\subsection{Forest governance in Uganda today}

Following the implementation of the new National Forestry and Tree Planting Act of 2003, the Forest Department was replaced with an autonomous National Forestry Authority (NFA) to manage central forest reserves, which comprise about 1.2 million ha (NFA 2005). The NFA remained in the same ministry (currently known as the Ministry of Water and Environment) as the former Forest Department, but it ceased operating in the traditional civil service structure, and was transformed into a body with a governing board that reports directly to the line minister. As an autonomous institution with powers, the NFA has the authority to act without interference from powerful actors in society. The Forest Department was susceptible to the machinations of government bureaucracy since no law made it autonomous and it could sue or be sued. It should be mentioned that although its mandate is limited to the central forest reserves ( $5.6 \%$ of total 'forested lands'), according to the 2001 forest policy, these lands have the largest proportion of cover (estimated at 64\%).

In an effort to empower local stakeholders, the new forest policy institutionalized collaborative forest management (CFM) and public-private partnerships in forestry investments. The assumption was that greater involvement by local communities and the private sector would create an environment conducive to sustainable forest management because of improved decision-making, transparency and accountability in the forest sector (GoU 2001).

It was envisaged that the new regulations and policy instruments would encourage local communities, private companies and local governments to participate in forest management. Proponents of these reforms argued that forests were more prone to degradation, if managed by a single agency operating alone, as had been the case under the 
Forest Department, which allowed little active involvement by other actors, especially local communities and the private sector (Kamugisha 1993; Banana et al. 2007).

\subsubsection{Collaborative forest management (CFM)}

The National Forestry Authority, which is responsible for the management of central forest reserves, has signed 32 agreements (covering about $2-4 \%$ of the total reserves) with communitybased organizations to 'co-manage' the reserves. It is reported that illegal activities have significantly reduced in reserves where CFM agreements have been signed because local communities are involved in policing and patrolling them. There has been some success in Mount Elgon National Park, Mabira Forest Reserves and Budongo Forest Reserves in Uganda (Hoefsloot 1997; Mupada 1997). (It should be noted, however, that the label 'co-management' may refer to a range of decisionmaking and power-sharing arrangements that a government and community can enter into; it does not necessarily indicate that the community and government have equal say in determining how the resource is to be managed.)

While Otieno and Buyinza (2010) reported that local communities are reportedly motivated to protect the reserves through CFM arrangements because of access to certain forest resources, Gombya-Ssembajjwe (1998) reported that in some parts of Uganda such as Butto-Buvuma Forest Reserve, CFM has failed. No studies have assessed the impacts of CFM on the livelihoods of local communities and/or on the ecological integrity and sustainability across all the reserves where agreements have been signed. However, there are a few case studies, which indicate real improvements in the forest condition (Turyahabwe et al. 2013). Currently, CFM is being applied in forest reserves that are severely degraded and that do not generate any timber revenues. However, participating communities benefit from the partnership agreements through increased access to non-timber forest products and ecotourism.

\subsubsection{Private-public partnerships}

The Forest Policy of 2001 recognizes the private sector as a partner in enhancing sustainable forest management. As a result, individuals have more avenues to establish forest plantation businesses. Before the policy was formulated, ownership of private forests followed the land-tenure regimes prescribed in the Land Act of 1998. Public-private partnerships between the NFA and individuals are on the rise and it is envisaged that this will enable an increase in total tree cover across the country. It is estimated that investment in commercial timber plantation grew from USD\$2 million in 2002 to USD\$ 9 million in 2008. By 2008, 35,000 ha of new plantations had been established.

\subsubsection{Local forest reserves (managed by District Forest Services)}

The District Forest Services (DFS) were created under the district governments to manage local forest reserves and forests on public lands and to provide advisory services to individuals involved in tree-growing. Local forest reserves make up 5000 ha (NFA 2005). Local forest reserves were expected to boost local communities' engagement in forest investments and conservation. However, government records indicated that they are of limited effectiveness because of financial and technical constraints (Obua et al. 2010). During the period 1990-2005, forest cover outside protected areas was cleared at a rate of $2.3 \%$ per year; inside protected areas, the deforestation rate was $0.8 \%$ per year. This is partly because of the poor forest governance characteristic of most districts of Uganda. Most district governments see forests as a source of revenue because most districts have a very narrow tax base.

The DFS have inadequate technical and financial capacity to complete their tasks, as set out in the policy and the Act, and this has rendered them ineffective (Turyahabwe et al. 2007). Through statutory instruments, some forest reserves that were previously under the Forest Department were gazetted as national parks, among them Mount Elgon National Park, Kibale National Park and Bwindi Impenetrable National Park. The change in status from forest reserves to national parks restricted local communities' access to these forests, which negatively affected their livelihoods. It was held that, as these forest reserves had far-reaching ecological benefits, their protection status had to be strengthened to national park status to protect their biodiversity and decrease their vulnerability to climate change.

\subsubsection{Management of national parks}

The Government of Uganda, having recognized that past approaches to wildlife conservation did not adequately protect Uganda's wildlife, reviewed the Wildlife Policy 1995 and enacted the Wildlife Statute in 1996. The statute created the Uganda Wildlife Authority (UWA), which was given a 
statutory mandate to manage Uganda's wildlife. A protected area system based on two classifications was established, namely wildlife conservation areas, which included national parks and wildlife reserves under the UWA, and wildlife management areas, which include sanctuaries and community wildlife areas. Approximately $9.3 \%$ of Uganda's total forested land is managed under the wildlife policy and Act, with UWA having the authority to dictate their management.

In general, consumptive use of these forests is restricted, and they seem to be safe from encroachment because of the extreme protectionist approach applied by UWA. 


\section{Climate change adaptation and mitigation policy regime in Uganda}

\subsection{Overview of the primary policies affecting vulnerability}

Almost every policy adopted by a government is likely to have some direct or indirect impact on the vulnerability of Mount Elgon's residents to climate change. This review focuses mostly on those policies that have direct impacts on the livelihood activities of the residents of the areas surrounding Mount Elgon National Park, who rely mostly on land and forest resources. We provide an overview of each of the policies and plans, their primary objectives and examples of the main activities being carried out around Mount Elgon by their respective ministries and departments.

\subsubsection{National development plan (NDP)} The national development plan (NDP) (GoU $2010 \mathrm{~b}$ ) is the policy framework that the Government of Uganda is applying to guide the formulation of government policy and the implementation of government programs. The aim of this plan is to achieve the national vision of transforming Uganda from a peasant society to a modern and prosperous country in 30 years. Climate change is not well addressed in the NDP; the plan includes a disaster management subsector, whose objectives focus on disaster impacts, disaster preparedness, risks and management, although not climate change adaptation. The NDP recognizes forestry as an important sector for stimulating national development. However, it acknowledges that forest cover has declined over the years and states that deliberate efforts ought to be made to reverse this trend. To achieve this goal, the plan sets out the following objectives:

- Restore forest cover from 3,604,176 ha to $4,933,746$ ha by 2015 .

- Restore degraded natural forests in forest reserves and private forests.

- Reduce pressure on forests as a source of fuelwood and construction material.

Although the NDP highlights the importance of forestry and sets out strategies for increasing forest cover, deforestation has continued unabated. This has been linked to institutional weaknesses and challenges (Petursson et al. 2011).

\subsubsection{Disaster preparedness and management policy (DPM) 2010}

The goal of the disaster preparedness and management policy (DPM) is to establish institutions and mechanisms that will reduce the vulnerability of people, livestock, plants and wildlife to disasters in Uganda. The policy calls for an approach to disaster management that focuses on reducing risk: the risks of loss of life, economic loss and damage to property. Climate change is mentioned as one of the issues that needs to be addressed. The policy calls for proactive efforts to reduce the causes and the negative impacts of climate change. It proposes that government develop climate change adaptation and mitigation measures.

The policy focuses on disaster preparedness, early warning systems, disaster response, disaster mitigation and recovery programs. It defines disasters as "a serious disruption of society, causing widespread human, material or environmental losses that exceed the capacity of the affected society to cope with unaided". However, this definition does not clearly define what constitutes 'a serious disruption'. Gazetting disaster-prone areas and resettling the population are some of the policy actions proposed in this policy as adaptation measures to challenges linked to climate change. The policy also provides policy actions to address drought, floods, landslides and mudslides, all of which are facets of climate change. Afforestation is one of the actions mentioned in the policy. However, the policy actions proposed for addressing the challenges of climate change are not accompanied by specific strategies.

\subsubsection{Environment policy (1995)}

The environment policy (1995) (GoU 1995) is the umbrella framework that recognizes the importance of the conservation and restoration of ecosystems, biodiversity and ecological processes. It recognizes the need to reorient national and local efforts to address environmental problems in a complete and integrated manner. The policy recommends the following key strategies for achieving environmental sustainability in Uganda: creation of an institutional and legal framework, development of a new sustainable culture, revision and modernization of sectoral 
policies, legislation and establishment of an effective monitoring and evaluation system. The policy also recognizes climate as a vital natural resource necessary for socioeconomic development and observes that increased or intensified droughts and floods are major indicators of climate change.

The focus on addressing climate change in this policy hinges on monitoring the climate and atmosphere to guide land use and economic decisions. Most of the strategies are geared toward strengthening the agencies responsible for climate monitoring. No climate change mitigation and adaptation strategies are proposed in this policy.

\subsubsection{Energy policy, 2002}

The goal of the energy policy (2002) (GoU 2002)

is "to meet the energy needs of the Ugandan population for social and economic development in an environmentally sustainable manner". However, much as the policy recognizes the need to address factors that have harmed the environment and to comply with international commitments, it does not clearly elaborate on how climate change and disaster risk reduction will be addressed. Rather, it gives the impression that, by adopting alternative energy sources and conducting environmental impact assessments whenever an energy project is designed, climate change issues will automatically be addressed. The policy does not include any comprehensive provisions for addressing climate change and disaster risk reduction, mitigation or adaptation. The policy recognizes that fuelwood requirements have contributed to degradation of forests and, in response, calls for efficient use of energy resources. It also proposes the use of renewable energy, notably solar, wind, geothermal and hydropower. If well implemented, therefore, this policy would lead to improved energy efficiency among households and other biomass users; it has the potential to slow the ongoing loss of forest cover.

The policy defines the energy sector as comprising four subsectors: fuelwood, petroleum products, electricity, and new and renewable sources of energy. However, increasing energy demand due to population growth is intensifying the pressure on forests and woodlands, and leading to degradation.

\subsubsection{Agriculture sector development strategy and investment plan (DSIP), 2010}

The development strategy and investment plan (DSIP) (GoU 2010a) is intended to increase agricultural production in Uganda in an environmentally sustainable manner. The policy provides for enhanced productivity by improving farmers' access to agricultural information and technology through the National Agricultural Advisory Services (NAADS).

A driving principle of the DSIP is that agriculture has a central role to play in the nation's development, economic growth and poverty reduction. Climate change is identified as one of the challenges that affect Uganda's agricultural output.

The policy acknowledges that Uganda does not have preparedness plans for adapting to climate change and therefore remains exposed and vulnerable. It recommends the development of plant and animal varieties that are resilient or resistant to climate variability/change as a strategy for adaptation. However, the policy does not elaborate on how agriculture can thrive with current climatic changes.

The DSIP further acknowledges that agricultural activities can result in the loss of forests and wetlands and hence loss of biodiversity. The plan proposes to integrate environmental management into all development programs to address this challenge, as required in the national legal framework. However, the DSIP does not appear to offer any strategies for ensuring that agricultural expansion and productivity do not jeopardize the condition of Uganda's forests. This oversight leaves forests susceptible to agricultural encroachment and hence deforestation, which may ultimately exacerbate climate change scenarios.

\subsubsection{National land use policy, 2007}

The national land use policy of 2007 (GoU 2007a) acknowledges that land and land resources are the country's most important natural resources. The overall goal of the policy is "to achieve sustainable and equitable socioeconomic development through optimal land management and utilization in Uganda". It notes that climatic variability is responsible for the current trends of drought and desertification in Uganda and calls for better monitoring systems and coping strategies to deal with these adverse impacts. Farmers' practice of cultivating marginal lands and fragile ecosystems is identified as one major land-use issue that has led to reduced land productivity, loss of biodiversity, environmental degradation and loss of microclimate regulation. It proposes strategies that would encourage behavior change among farmers, but not strategies for how they can mitigate the associated impacts of their practices or adapt to the vagaries of climate change. 
The policy also acknowledges that deforestation due to shifting cultivation, especially in ungazetted areas, is another key land-use issue in Uganda.

Another element of the national land use policy is the recognition that tropical high forests are vulnerable to extensive slash-and-burn agriculture, common in shifting cultivation. The land use policy suggests that some other policies in Uganda - notably policies related to urbanization and industrial expansion - do not support protected areas, especially forest estates. Protected areas that have been affected include Namanve Forest (1000 ha), Wabisi-Wajala (8744 ha), Butamira Forest (13,000 ha), Walulumbu Forest Reserve (2567 ha), and the conversion of periurban forest reserves for commercial and settlement purposes in Mbale, Soroti, Kabale, Fort Portal and Gulu districts. Proper and conventional land evaluation processes are often not followed in the conversion of these forest estates.

The policy also notes the lack of legal provisions addressing overgrazing and poor farming techniques such as shifting cultivation, which also contribute to the extensive and unnecessary clearing of woody vegetation, which has led to the depletion of forests, especially on private land. The policy points out that the government approach to modernizing of the economy requires better infrastructure, using the transportation and energy sectors, and that the benefits of road construction and rehabilitation have major costs in terms of environmental damage. Vegetation is necessarily cleared to build roads and, in areas where the road is to pass through a forested area, part of the forest is inevitably lost. However, although the policy notes these issues, it does not propose specific strategies for dealing with them.

\subsubsection{Forest policy, 2001}

The national forest policy (GoU 2001) was formulated in response to the deterioration in condition of the country's forests. The overall goal of this policy is to achieve "an integrated forest sector that achieves sustainable increases in the economic, social and environmental benefits from forests and trees by all the people of Uganda especially the poor and vulnerable". The policy recognizes the need to protect watershed and soil conservation forests given their importance for ameliorating the impacts of droughts. It also acknowledges the importance of participating in international obligations such as the United Nations Framework Convention on Climate Change (UNFCCC). Despite acknowledging the importance of forests in climate change mitigation, the policy does not elaborate on how people can apply this principle in practice.

\subsubsection{National water policy, 1997}

The national water policy (GoU 1997) sets out the framework for water resource management and development. Its underlying principle is that fresh water is a key strategic resource, vital for sustaining life, promoting development and maintaining the environment. The policy suggests that the main threat to water resources is negligence in human activities. It also acknowledges seasonal and spatial variability in water resources, variations between distinct wet and dry years, considerable variation in the timing of the onset of seasons, and variations in the amount of rainfall and stream flows as common phenomena in Uganda that need to be addressed.

One of the objectives in this policy is "to promote development of water supply for agriculture production in order to modernize agriculture and mitigate effects of climatic variations on rain-fed agriculture". The policy's strategies for achieving this objective mainly lie in empowering farmers so they can invest in irrigation, especially in semiarid and drought-prone areas because in dry areas, surface water resources are generally seasonal and groundwater potential is often limited. The policy acknowledges that sectoral water-use policies and plans are important. It mentions agriculture, energy and forestry as sectors that ought to be formulating policies that fit with the goals of the water policy. The policy does not propose specific measures to address challenges with water resources resulting from climate change and does not offer ecosystem management as a strategy to increase water productivity. The fact that this policy does not mention the role of forests in protecting water catchments indicates that it was probably not seen as critical during the policy processes that culminated in this policy.

\subsubsection{National policy for the conservation and management of wetland resources, 1994}

The aim of the national policy for the conservation and management of wetland resources (GoU 1994 ) is to conserve Uganda's wetlands to sustain their ecological and socioeconomic functions for the present and future well-being of the people. It recognizes the ecological value of wetlands, as they maintain the water table, provide a continuous supply of water and prevent erosion, among other services. 
The policy recognizes the value of promoting and actively participating in regional and international efforts to conserve and sustainably use wetlands, and encourage the involvement of other countries in the conservation of wetland resources. However, the policy is silent on how wetlands can be used to mitigate climate change and help communities adapt to the challenges associated with climate change. Furthermore, the policy does not mention deforestation as one of the problems that can affect wetland integrity. It is argued that deforestation can have an indirect effect on wetlands by affecting water flow and sedimentation.

\subsubsection{0 (Draft) climate change policy, 2012}

A national climate change policy is being drafted by the Government of Uganda. The draft national climate change policy (GoU 2012) states that "adaptation to climate change in Uganda requires a series of coordinated policy responses that are either sector specific or cross-cutting in nature". The policy recognizes the need to act upon a number of sector-specific priorities to increase the resilience of the country's development path to the impacts of climate change and to contribute to the reduction of atmospheric greenhouse gas emissions. According to the current draft, a climate change unit is to be established within the Ministry of Water and Environment to act as the focal climate change institution, with the following functions:

- acting as an information clearinghouse on climate change concerns

- providing policy and strategic advice on climate change

- supporting communication and outreach on climate change

- ensuring the integration of climate change concerns into overall national planning through coordination with the relevant ministries, departments and governmental agencies

- providing secretarial services to the National Climate Change Policy Committee

- monitoring the implementation of the climate change policy and its implementation strategy

- serving as the national focal point for the United Nations Framework Convention on Climate Change (UNFCCC).

Each of the ministries, departments and agencies with a role to play in the implementation of the proposed policy responses is expected to designate a departmental focal point that will be accountable for the implementation of the prescribed policy responses that concern their department. The complete list of climate change adaptation and mitigation policy responses for a range of sectors is provided in Appendix 1.

Overall, the draft climate change policy is comprehensive and the adaptation and mitigation policy instruments suggested are exhaustive and feasible. The main weakness observed in the policy is that many government institutions and departments will be involved in its implementation, and therefore monitoring and evaluation of the implementation process may be difficult to achieve. The implementation structure proposed is too big and complex, if we wish to achieve efficiency and effectiveness in its operationalization.

A National Climate Change Advisory Committee will ensure working-level coordination and provide technical input to the National Climate Change Policy Committee. It will bring together technical representatives from the various government departments at the national level, along with representatives from private sector associations, civil society, academia and district authorities.

At the district level, a climate change focal point is expected to be anchored within the natural resources department of each district government; all departments will ensure that climate change issues in their sectors are integrated into the district development plans. The role of the proposed National Climate Change Policy Committee is to coordinate policy implementation and ensure information flow on resource allocation for the implementation of the policy. The committee will be chaired by the prime minister and will bring together ministers from relevant departments.

\subsubsection{National adaptation programmes of action (NAPAs)}

Although Uganda does not yet have a policy on climate change and climate change adaptation $(\mathrm{GoU}$ 2007b), it signed the United Nations Framework Convention for Climate Change in 1992 and ratified it on 8 September 1993; the UNFCCC provides an international framework for mitigating climate change at both international and local levels. NAPAs were developed in response to the decision made at the seventh Conference of the Parties to the UNFCCC (COP7) in Marrakesh, Morocco, which aims to enhance quick responses to, and communication on, urgent and immediate adaptation needs in least developed countries. Uganda also ratified the Kyoto Protocol, which provides the basis for an international response to the challenges of climate change. By signing and ratifying 
both the UNFCCC and Kyoto Protocol, Uganda became legally obliged to adopt and implement policies and measures designed to mitigate climate change and to adapt to the impacts resulting from climate change.

The NAPA lists climate change impacts in the context of trends such as: rapid population growth, agricultural production, water availability, food security, health, education, infrastructure development, energy, deforestation/forestry, wildlife, weather and climate information and the fact that $94 \%$ of rural Ugandans use wood or charcoal as fuel (GoU 2007b). The NAPA recognizes that climate change contributes greatly to conflicts and disasters in Uganda.

Table 3. Thematic priority areas for investment in Uganda's NAPA

\begin{tabular}{ll}
\hline Priority area & Ranking \\
\hline Land and land use & 1 \\
Farm forestry & 2 \\
Water resources & 3 \\
Health & 4 \\
Weather and climate information & 5 \\
Indigenous knowledge documentation & 6 \\
and awareness creation & \\
Policy and legislation & 7 \\
Infrastructure & 8 \\
Alternative livelihoods & 9 \\
\hline
\end{tabular}

Source: GoU (2007b)
The nine priority areas identified in Uganda's NAPA are listed in Table 3.

This list of thematic areas was developed into nine projects to be implemented with an initial budget for projects targeting the most urgent intervention sites of USD\$23.3 million (see Table 4). Most of these projects justify their interventions because of the need to compensate for the loss of natural forests and associated ecosystem services - erosion control, increased flooding and landslides, shortage of fuelwood and pasture, and loss of biodiversity. However, only one of these projects appears to address the underlying cause of the climate adaptation challenges in any way (project \#2).

It is evident that addressing deforestation was not explicitly included in any of the priority areas in the NAPAs, despite evidence that forests provide alternative livelihood opportunities under various climate change scenarios.

\subsubsection{Nationally appropriate mitigation actions (NAMAs)}

The NAMA concept was first established at the 13th Conference of the Parties (COP13) in 2007, yet a registry of proposed NAMAs was only developed at COP17 in Durban (2012). Consequently, Uganda has not yet developed any NAMAs, although feasibility studies have been conducted for the following two NAMA proposals involving

- development of grid-connected renewable energy;

- sustainable charcoal in Uganda.

Whereas the feasibility study for the latter reveals clear implications for addressing issues related to deforestation and the consequent deterioration in

Table 4. NAPA priority projects for Uganda

\begin{tabular}{llll}
\hline \multirow{2}{*}{ No } & \multirow{2}{*}{ Project title } & \multicolumn{2}{l}{ Immediate and urgent interventions across ecosystems } \\
\cline { 3 - 4 } & Limited area interventions & Countrywide interventions \\
\hline 1 & Community tree growing & 3.2 & 5.5 \\
2 & Land degradation management & 2.5 & 4.7 \\
3 & Strengthening meteorological services & 4.2 & 6.5 \\
4 & Community water and sanitation & 2.8 & 4.7 \\
5 & Water for production & 4.0 & 5.0 \\
6 & Drought adaptation & 2.0 & 3.0 \\
7 & Vectors, pests and disease control & 3.5 & 8.0 \\
8 & Indigenous knowledge (IK) and natural & 0.6 & 1.2 \\
& resource management & & 1.2 \\
9 & Climate change and development planning & 0.5 & \\
\hline
\end{tabular}

Source: GoU (2007b) 
ecosystems and in the services they provide to rural households, the authors appear to focus exclusively on improving the value chain after the charcoal has been produced (Basu et al. 2013). Therefore, although touted as having the potential to address challenges holistically, this study concentrated only on improving efficiency in the middle portions of the value chain (production, transportation and, to a lesser degree, retail). None of the feasibility studies appears to make any attempt to assess how Uganda can best reduce deforestation in protected areas or how to increase onfarm sequestration of carbon through tree-cropping, agroforestry or enhanced agricultural techniques.
In the context of Mount Elgon, the UN Development Programme (UNDP) is implementing a project in the districts of Mbale, Manafwa and Bududa to realize low-carbon and climate change resilient development. The districts are expected to develop their integrated territorial climate plans, which will fully integrate climate change adaptation and mitigation strategies into their planning. The project will enable the region to address the priorities as provided in Uganda's NAPA (see http://www. undp.or.ug/index.php/what-we-do/energyenvironment).

Table 5. Summary of the national policy and related climate change component

\begin{tabular}{|c|c|}
\hline Primary policy & Climate change component \\
\hline $\begin{array}{l}\text { National development plan (NDP) } \\
2010\end{array}$ & $\begin{array}{l}\text { The NDP does not adequately capture climate change, although it has a sub- } \\
\text { sector of disaster management that reflects climate change whose objectives } \\
\text { only seem to focus on disaster impacts, disaster preparedness, risks and } \\
\text { management, but not climate change adaptation. }\end{array}$ \\
\hline $\begin{array}{l}\text { Disaster preparedness and } \\
\text { management policy (DPM) } 2010\end{array}$ & $\begin{array}{l}\text { Policy mentions climate change as one of the issues that need to be addressed } \\
\text { and calls for proactive action to climate change mitigation and adaptation }\end{array}$ \\
\hline Environment policy 1995 & $\begin{array}{l}\text { Recognizes as a vital resource for socioeconomic development. The policy } \\
\text { focuses on monitoring the climate and atmosphere with the purpose of guiding } \\
\text { land use and economic decisions }\end{array}$ \\
\hline Energy policy 2002 & $\begin{array}{l}\text { It mentions climate change, but does not clearly elaborate on how climate } \\
\text { change and disaster risk reduction will be addressed. }\end{array}$ \\
\hline $\begin{array}{l}\text { Agriculture sector development } \\
\text { strategy and investment plan } \\
\text { (DSIP) } 2010\end{array}$ & $\begin{array}{l}\text { Identifies climate change as one of the challenges that affect Uganda's } \\
\text { agricultural output. Recommends the development of plant and animal } \\
\text { varieties that are resistant to climate change as a strategy for adaptation }\end{array}$ \\
\hline National land use policy 2007 & $\begin{array}{l}\text { Policy notes climate variability as responsible for current trends of drought and } \\
\text { desertification and calls for better monitoring and coping strategies }\end{array}$ \\
\hline Forest policy 2001 & $\begin{array}{l}\text { Acknowledges importance of participating in international obligations such as } \\
\text { the UNFCCC }\end{array}$ \\
\hline National water policy 1997 & $\begin{array}{l}\text { Suggests negligence in human activities as main threat to water resources. } \\
\text { Does not propose specific measures to address challenges with water resources } \\
\text { resulting from climate change }\end{array}$ \\
\hline
\end{tabular}

National policy for the conservation and management of wetland resources 1994

Draft climate change policy 2012

National adaptation programs of action (NAPAs) 2007

Nationally appropriate mitigation actions (NAMAs)
Policy is silent on how wetlands can be used to mitigate climate change and help communities adapt to challenges associated with climate change

The policy recognizes the need to act upon a number of sector-specific priorities to increase the resilience of the country's development path to the impacts of climate change and to contribute to the reduction of atmospheric greenhouse gas emission.

NAPA lists climate change impacts in the context of trends such as: rapid population growth, agricultural production, water availability, food security, health, education, infrastructure development, energy, deforestation/forestry, wildlife, weather and climate information

Uganda has not yet developed any NAMAs although feasibility studies have been conducted for development of grid-connected renewable energy and sustainable charcoal in Uganda 


\section{Interaction of policies and their impacts in Mount Elgon}

\subsection{Current policy implementation on Mount Elgon}

Some of the policies and plans described above are being implemented in areas around Mount Elgon. Under the objective of achieving household food and nutrition security in the agriculture sector development strategy and investment plan (DSIP) 2010, the following activities are underway in the Mount Elgon region:

- High-yielding hybrid maize has been introduced to farmers to improve food security.

- Farmers are being given technical knowledge and inputs through National Agricultural Advisory Services (NAADS) to increase productivity; inputs include improved seed, breeds of animals and fertilizers in all districts surrounding Mount Elgon.

The national land use policy objective of devising better monitoring systems and coping strategies to ameliorate the adverse impacts of climate variability is being implemented in this region, as seen in the following:

- The Meteorology Department gives regular weather forecasts to warn inhabitants of areas around Mount Elgon that are susceptible to landslide.

- Some communities from areas susceptible to landslides around Mount Elgon have been resettled in Kiryandongo district in western Uganda, an area that is free of such risks.

To achieve the forest policy objective of reducing household dependence on natural forests, the following activities are underway in the Mount Elgon region:

- Many households have begun using agroforestry practices.

- Farmers have established woodlots for poles, timber and fuelwood.

- Degraded parts of Mount Elgon National Park are being reforested as part of the UWA FACE project.

- Woodlots are being established on private land for carbon funds, by ECOTRUST.
- The Farm Income Enhancement and Forest Conservation Project (FIEFOC) is providing tree seedlings for households to have their own woodlots.

To regulate the use and trade of all products from the permanent forest estate and to promote the use of lesser-known species, the following measures are being taken:

- District Forest Officers are using a licensing system throughout the entire Mount Elgon area to prevent unsustainable harvesting of forest products.

- Collaborative partnerships with rural communities for sustainable forest management are common in this region.

- UWA is co-managing some parts of Mount Elgon National Park with local communities.

To promote conservation of forest biodiversity, UWA is managing most parts of Mount Elgon as a national park as a strategy for protecting montane biodiversity.

To achieve the rehabilitation and conservation of forests that protect the soil and water in the country's key watersheds and river systems, the following measures are underway:

- Mount Elgon Regional Ecosystem Conservation Programme (MERECP) by the International Union for Conservation of Nature (IUCN) is supporting several community-based organizations in restoring degraded watersheds.

- The UWA/FACE project is helping to restore community forests and watersheds by supporting communities in planting trees.

- The Farm Income Enhancement and Forest Conservation Project (FIEFOC) is supporting communities to plant trees around catchment areas.

To achieve the aims of the water policy, the following measures are being implemented:

- Most of the districts around Mount Elgon have a water engineer to provide technical expertise on water management.

- All districts are benefiting from grants from the central government to increase the rural water supply. 
To end practices that reduce wetland productivity, the National Environment Management Authority has begun litigation against individuals who built in wetlands in Mbale and neighboring districts around Mount Elgon.

Most districts now have wetland management plans to ensure the sustainable management of this important ecosystem.

\subsection{District-stakeholder priorities for achieving adaptation and mitigation objectives}

In its inception phase, this project conducted a series of national, district and village-stakeholder workshop to identify key issues relevant to this policy analysis. Later, as part of a preliminary ground-truthing of this analysis, the key observations from this report were shared with district stakeholder from stakeholders from Bududa and Kapchorwa districts in the Mount Elgon area.
Based on this analysis of the range of policies, districtlevel stakeholders identified the forest, wildlife and agriculture policies as the policies, and their respective programs, as having the most significant impacts on forests, ecosystem services, livelihoods, and climate change adaptation or mitigation objectives in the Mount Elgon area . In the forest sector, participants identified promotion of agroforestry, reforestation of degraded hill slopes, watershed management and use of non-timber forest products as the most important strategies for addressing climate change issues and livelihoods in the Mount Elgon region.

In the agriculture sector, participants identified improvements in household food and nutrition security and increased farmer access to improved technologies as the most relevant ways of mitigating the impacts of climate change in the Mount Elgon region. Gazettement of Mount Elgon as a national park, as set out in the wildlife policy, was identified by stakeholders as important for the provision of ecosystem services and livelihoods in the region, although negative impacts on livelihoods immediately surrounding community livelihoods were also acknowledged as an ongoing source of tension. 


\section{Proposed policy implementation pathway}

In this project, we envisage using a bottom-up approach to influence local and national policy discourse using our findings. Indicators of impact will be the adoption of our findings at each level of the various policy processes. Figure 2 shows the policy implementation pathway that we intend to use to influence policy direction.

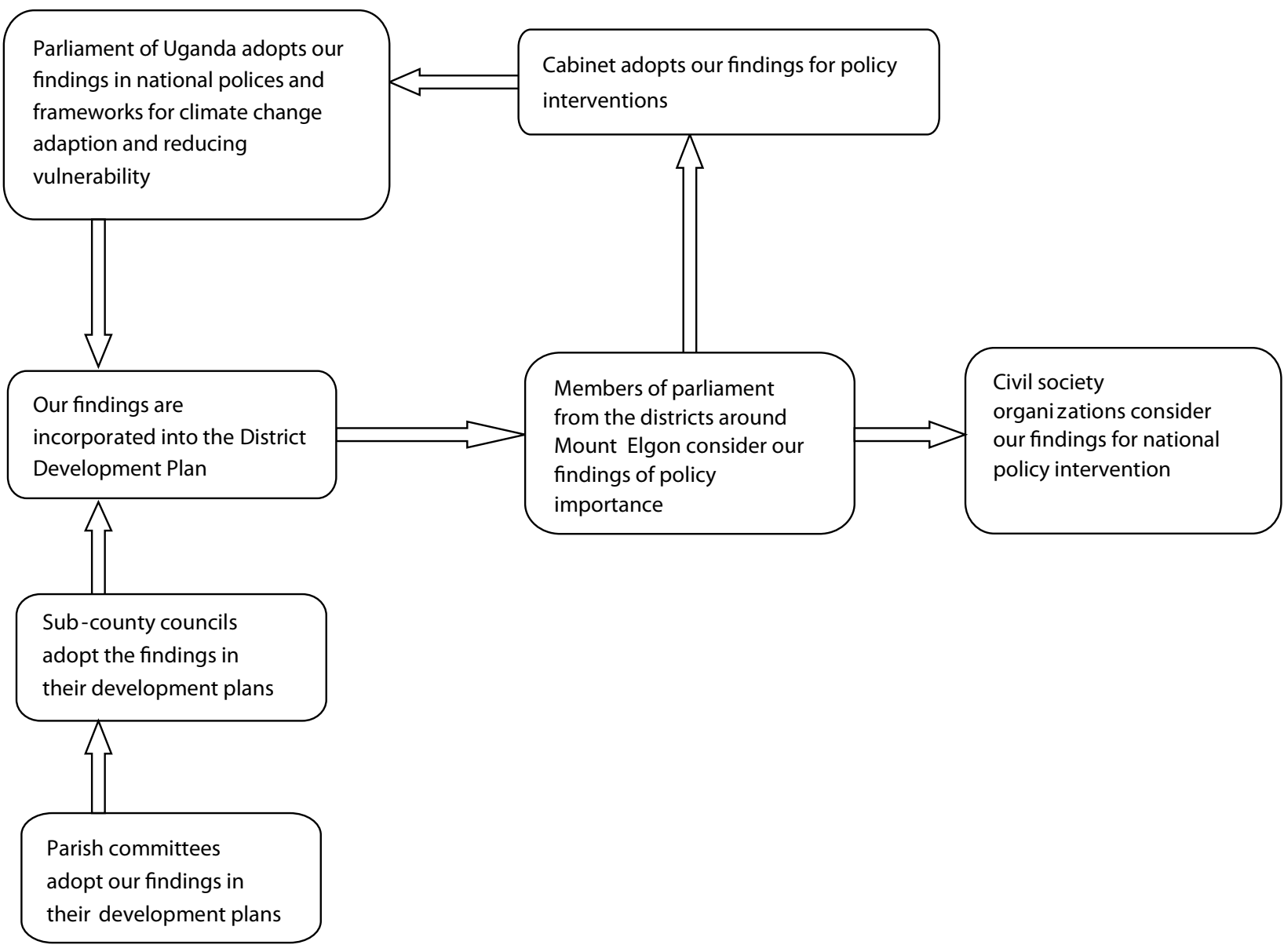

Figure 2. Policy implementation pathway 


\section{Conclusions and recommendations}

Governments around the Mount Elgon area have an opportunity to tailor their climate change adaptation strategies to the national frameworks, which seem to be quite comprehensive. Local leaders need only to explore feasible and locally adaptive measures for the particular challenges of each context. However, the policy framework on climate change adaptation does not provide for tailored local institutions that would ensure that the strategies and programs proposed are actually implemented.

This may create a situation of 'free riding' with the knock-on effect of increasing vulnerability to climate change among the communities around Mount Elgon. This policy review has revealed the areas, levels and actors that are potentially critical if our subsequent studies are to have a policy impact. Most policy processes begin from the top and rural communities are simply recipients of what the national leaders perceive as appropriate. Although the existing policy environment seems to be conducive to achieving improvements in adaptation and reductions in vulnerability, the desire to achieve economic growth through implementation of the DSIP may prove a source of conflict with other policies whose purpose is to conserve resources that would improve the resilience of the Mount Elgon ecosystem.

There is need for further exploration of possible synergies between policies in the pursuit of improved adaptation and reduced vulnerability. Programs on adaptation and mitigation to climate change must also be consolidated and harmonized to benefit from economies of scale and synergies. In addition, there is need for the role of forests in ecosystem services to be recognized in the NAPAs. 


\section{References}

Adger WN, Agrawala S, Mirza MMQ, Conde C, O'Brien KL, Pulhin J, Pulwarty R, Smit B and Takahashi K. 2007. Climate change 2007: Impacts, adaptation, and vulnerability. In Parry ML, Canziani OF, Palutikof JP, van der Linden PJ and Hanson CE, eds. The Fourth Assessment Report of the Intergovernmental Panel on Climate Change. Cambridge, UK: Cambridge University Press. 717-43.

Banana AY, Buyinza M, Luoga E and Ongugo P. 2010. Emerging local economic and social dynamics shaping East African forested landscapes. In Mery G, Katila P, Alfaro RI, Kanninen M, Labovikov M and Varjo J, eds. Forests and Society: Responding to Global Drivers of Change. IUFRO World Series, Vol. 25. Vienna: IUFRO. 315-35.

Banana AY, Namaalwa JJ, Byakagaba P, Waiswa D, Buyinza M, Gombya-Ssembajjwe W. 2014. The impacts of decentralisation reforms on sustainable forest management in Central Uganda. In Katila P, Galloway G, de Jong W, Pacheco P, Mery G, eds. Forests under PressureLocal Responses to Global Issues. IUFRO World Series Vol. 32. Vienna. 357-367.

Banana AY, Ongugo PO, Gombya-Ssembajjwe WS, Gole TW, Senbeta F, Namaalwa J, Luoga E, Bahati J, Mbwambo LA, Graw V, Gatzweiler FW. 2013. Forest Governance Reforms in Eastern Africa: A Comparative Analysis of Institutional, Livelihood and Forest Sustainability Outcomes. In Gatzweiler FW, ed. Institutional and Livelihood Changes in East African Forest Landscapes: Decentralization and Institutional Change for Sustainable Forest Management in Uganda, Kenya, Tanzania and Ethiopia. Peter Lang International Academic Publishers. Frankfurt am Main, Berlin, Bern, Bruxelles, New York, Oxford, Wien, 2013. XVI, 312 pp., 5 coloured fig., 4 b/w fig., 43 tables; ISBN 978-3-631-63462-2 pb.

Banana AY, Vogt ND, Bahati J and GombyaSsembajjwe W. 2007. Decentralised governance and ecological health: Why local institutions fail to moderate deforestation in Mpigi district of Uganda. Scientific Research and Essay 2(10):434-45.

Basu A, Blodgett C, Müller N and Soezer A. 2013. Nationally Appropriate Mitigation Action Study on Sustainable Charcoal in Uganda. Perspectives Climate Change and UNDP MDG Carbon. (http://mdgcarbonfacility.org/)
Becker C, Banana AY and Gombya-Ssembajjwe W. 1995. Early detection of forest degradation: An IFRI Pilot Study in Uganda. Environmental Conservation 22(1):31-38.

Beyaraza EK. 2004. Evolution of Property Rights in Uganda: A Legal and Philosophical Analysis of Past, Present and Future Trends. Makerere University.

Byakagaba P, Eilu G, Okullo JBL, Tumwebaze SB and Mwavu EN.2011. Population structure and Regeneration status of Vitellaria paradoxa (C.F. Gaertn.) under different land management regimes in Uganda. Agricultural Journal 6(1):14-22.

Chambers R. 1992. Rural Appraisal: Rapid, Relaxed and Participatory. IDS Discussion Paper No. 331, Brighton, Sussex.

[FAO] Food and Agriculture Organization of the United Nations. 2007. State of the World's Forests. Rome: FAO.

Gombya-Ssembajjwe WS. 1995. Sacred forests in modern Ganda society. Uganda Journal 43:32-44.

Gombya-Ssembajjwe W and Banana A. 1998. Property rights and the sustainability of forests in Uganda. Presentation, Land Reform Revisited: Access to Land, Rural Poverty and Paction, at Vancouver, British Columbia.

[GoU] Government of Uganda. 2012. The national draft climate change policy. Entebbe: Government of Uganda.

[GoU] Government of Uganda. 2010a. Agricultural sector development strategy and investment plan. Entebbe: Government of Uganda.

[GoU] Government of Uganda. 2010b. National development plan 2010/11-2014/15. Entebbe: Government of Uganda.

[GoU] Government of Uganda. 2009. National budget framework paper for financial year 2010/2011. Kampala: Ministry of Finance, Economic Planning and Development.

[GoU] Government of Uganda. 2007a. The national land use policy. Entebbe: Government of Uganda.

[GoU] Government of Uganda. 2007b. Climate change: Uganda national adaptation programmes of action. Entebbe: Government of Uganda.

[GoU] Government of Uganda. 2003. The national forestry and tree planting Act. Entebbe: Government of Uganda.

[GoU] Government of Uganda. 2002. The national energy policy. Entebbe: Government of Uganda. 
[GoU] Government of Uganda. 2001. The national forestry policy 2001. Entebbe: Government of Uganda.

[GoU] Government of Uganda. 1998. Land Act of Uganda 1998. Entebbe: Government of Uganda.

[GoU] Government of Uganda. 1997. National water policy. Entebbe: Government of Uganda.

[GoU] Government of Uganda. 1995. National environment policy. Entebbe: Government of Uganda

[GoU] Government of Uganda. 1994. National policy for the conservation and management of wetland resources. Entebbe: Government of Uganda.

Gray M and Kalpers J. 2005. Ranger-based monitoring in the Virunga-Bwindi region of East-Central Africa: A simple data collection tool for park management. Biodiversity and Conservation 14(11):2723-41.

Hoefsloot H. 1997. Collaborative management on Mt Elgon: An account of first experience. IUCN-The World Conservation Union, Nairobi, Kenya.

[IPCC] Intergovernmental Panel on Climate Change. 2014. Climate change 2014: Impacts, adaptation and vulnerability. Par A: A global and Sectoral aspects. Contribution of working group II to the fifth Assessment Report to the intergovernmental Panel on Climate Change. http://www.ipccwg2.gov/AR5/images/uploads/ WGIIAR5Frontmatters_Final.pdf

Jacovelli P and Caevalho J. 1999. The private forest sector in Uganda: Opportunities for greater involvement. Ministry of Water, Lands and Environment, Uganda.

Jomo KS, Chang YT and Khoo KJ. 2004. Deforesting Malaysia: The Political Economy and Social Ecology of Agricultural Expansion and Commercial Logging. London and New York: Zed Books.

Kamugisha JR. 1993. Management of natural resources in Uganda: Policy and legislation landmarks, 1890-1990. SIDA Regional Soil Conservation Unit, Nairobi.

Mayring PH. 2000. Qualitative Inhaltsanalyse. Grundlagen und Techniken. 7th ed.Weinheim: DeutscherStudienVerlag.

Muhweezi AB, Sikoyo GM and Chemonges M. 2007. Introducing a transboundary ecosystem management approach in the Mt. Elgon region. Mountain Research and Development 27(3):215-19.

Mupada E. 1997. Towards collaborative forest management in the conservation of Uganda's rainforests: A presentation on African rainforests and the conservation of biodiversity. Proceedings of the Limbe Conference, Cameroon 17-23 January, Earthwatch, Oxford, UK.
[MWE] Ministry of Water and Environment. 2011. State of Environment Report. Kampala: Ministry of Water and Environment.

Namaalwa J, Gombya-Ssembajjwe W and Hofstad O. 2001.The profitability of deforestation in Uganda. International Forestry Review 3(4):299-306.

Nampindo S, Phillips GP, Plumtree A, Rwestiba A, Langoya CD and Moya D. 2005. The impact of conflict in northern Uganda on the environment and natural resources management. World Conservation Society and USAID Environmental Brief No. 4.

[NFA] National Forestry Authority. 2005.Uganda's forests: Functions and classification. Kampala: National Forestry Authority.

Obua J, Agea JG and Ogwal JJ. 2010. Status of forests in Uganda. African Journal of Ecology 48(4):853-59.

Otieno AC and Buyinza M. 2010. Collaborative forest management in Uganda: A strategy for controlling deforestation in west Bugwe forest reserve, Busia district. Online Journal of Earth Sciences 4(2):95-102.

Petursson JG, Vedeld P and Kaboggoza J. 2011. Transboundary biodiversity management: institutions, local stakeholders, and protected areas. A case study from Mount Elgon, Uganda and Kenya. Society and Natural Resources 24(12):130421.

Plumptre AJ, Behangana M, Davenport T, Kahindo C, Kityo R, Ndomba E, Nkuutu D, Owiunji I, Ssegawa P and Eilu G. 2003. The biodiversity of the Albertine Rift. Albertine Rift Technical Reports Series 3:1-105.

Russell AJM, Locatelli B, Pramova E, Alumai GJ and Behr DC. 2013. Using forests to enhance resilience to climate change: What do we know about how forests can contribute to adaptation? Working Paper. Washington DC: Program on Forests (PROFOR).

Schwartz MW and Caro TM. 2003. Effect of selective logging on trees and understory regeneration in Miombo woodlands. African Journal of Ecology 41:75-82.

Transparency International. 2009. The 2009 Transparency International Corruption Perceptions Index. www.transparency.org.

Turyahabwe $\mathrm{N}$ and Banana AY. 2008. An overview of history and development of forest policy and legislation in Uganda. International Forestry Review 10(4):641-56.

Turyahabwe N, Geldenhuys CJ, Watts S and Obua J. 2007. Local organizations and decentralized forest management in Uganda: Roles, challenges and policy implications. International Forestry Review 9(2):581-96. 
Turyahabwe N, Tumusiime DM, Byakagaba $\mathrm{P}$ and Tumwebaze SB. 2013. Impact of collaborative forest management on forest status and local perceptions of contribution to livelihoods in Uganda. Journal of Sustainable Development 6(10):36-46.

[UBOS] Uganda Bureau of Statistics. 2007. Uganda National Household Survey 2005/2006: Report on the Agricultural Module. Kampala: UBOS.

[UFRIC] Uganda Forestry Resources and Institutions Center. 2008. Masaba and Kapchorwa Site Report: Third Visit June-Aug. 2008. IFRI/ SANREM-CRSP Report. Kampala:UFRIC, Makerere University.

Uganda Land Alliance. 1997. Customary land holding in Uganda: A case study of Lira and Apac districts. Uganda Land Alliance.
Van Heist M. 1994. Accompanying report with the Land unit map of Mount Elgon National Park. Mount Elgon conservation and development project, Mbale, Uganda (1994).

Vogt ND, Banana AY, Gombya-Ssembajjwe W and Bahati J. 2006. Understanding the stability of forest reserve boundaries in the West Mengo region of Uganda. Ecology and Society 11(1):38. http:// www.ecologyandsociety.org/vol1 1/iss1/art38/

White $S$ and Byakagaba P. 2010. Review of the Forestry Sector in Uganda. Proposals for Improving Governance and Effective Management in the Forestry Sector. UK: LTS International Limited.

Winterbottom B and Eilu G. 2006. Uganda Biodiversity and Tropical Forest Assessment. Washington, DC: International Resource Group. 


\section{Appendix 1. Strategies for addressing climate change}

\begin{tabular}{|c|c|}
\hline Sector & Strategies suggested in the draft policy \\
\hline \multirow[t]{6}{*}{ Water } & $\begin{array}{l}\text { Promote and encourage water harvesting and efficient water use among individuals, } \\
\text { households, institutions and sectors }\end{array}$ \\
\hline & $\begin{array}{l}\text { Promote and strengthen the conservation and protection against degradation of watersheds, } \\
\text { water catchment areas, river banks and water bodies }\end{array}$ \\
\hline & $\begin{array}{l}\text { Promote the integrated planning, development and management of water resources (including } \\
\text { underground water resources), including contingency planning for extreme events such as } \\
\text { floods and drought }\end{array}$ \\
\hline & Improve and strengthen trans-boundary cooperation regarding water resources \\
\hline & $\begin{array}{l}\text { Support institutional and human capacity building in water resource use, development and } \\
\text { management }\end{array}$ \\
\hline & Strengthen water resource monitoring networks and flood warning systems \\
\hline \multirow[t]{5}{*}{ Fisheries } & $\begin{array}{l}\text { Promote and encourage the adaptive management of fishing capacity based on climate and } \\
\text { environmental forecasts, to protect against extreme events }\end{array}$ \\
\hline & $\begin{array}{l}\text { Promote sustainable fish farming as a means of economic diversification and to reduce over- } \\
\text { fishing in inland lakes and rivers }\end{array}$ \\
\hline & $\begin{array}{l}\text { Promote awareness of the impacts of climate change on fisheries among stakeholders such as } \\
\text { local communities, resource managers and policy makers }\end{array}$ \\
\hline & $\begin{array}{l}\text { Provide economic incentives to diversify livelihood options to reduce dependence on climate- } \\
\text { sensitive fishery resources }\end{array}$ \\
\hline & Promote biological engineering and restoration of stress-tolerant organisms \\
\hline \multirow[t]{5}{*}{$\begin{array}{l}\text { Transportation and } \\
\text { public works }\end{array}$} & $\begin{array}{l}\text { Integrate climate change into the existing infrastructure risk assessment guidelines and } \\
\text { methodology }\end{array}$ \\
\hline & $\begin{array}{l}\text { Building on work already underway, establish and enforce climate change-resilient standards } \\
\text { for transportation and infrastructure planning and development through monitoring and } \\
\text { reporting systems }\end{array}$ \\
\hline & $\begin{array}{l}\text { Encourage the integration of climate change into transportation and infrastructure } \\
\text { development strategies }\end{array}$ \\
\hline & $\begin{array}{l}\text { Promote and encourage water catchment protection in transportation infrastructure } \\
\text { development and maintenance }\end{array}$ \\
\hline & $\begin{array}{l}\text { Climate-proof existing and future infrastructure by conducting geotechnical site investigations } \\
\text { (GSIs) to determine whether areas are appropriate or inappropriate for infrastructure } \\
\text { development }\end{array}$ \\
\hline \multirow[t]{6}{*}{$\begin{array}{l}\text { Forestry and } \\
\text { wetlands }\end{array}$} & $\begin{array}{l}\text { Strengthen the existing national forestry and wetlands policy to prevent forest and wetland } \\
\text { degradation and encroachment }\end{array}$ \\
\hline & $\begin{array}{l}\text { Promote intensified and sustained afforestation and reforestation programs implemented by } \\
\text { the government, institutions, households and individuals, the private sector, civil society and } \\
\text { multilateral organizations }\end{array}$ \\
\hline & Promote and intensify wetland protection and restoration of degraded wetlands \\
\hline & $\begin{array}{l}\text { Promote alternative energy sources, energy conservation initiatives and efficient biomass } \\
\text { energy production and use of technologies to reduce biomass consumption }\end{array}$ \\
\hline & $\begin{array}{l}\text { Encourage agroforestry, which will enable poor rural households to meet their subsistence and } \\
\text { energy needs }\end{array}$ \\
\hline & $\begin{array}{l}\text { Strengthen existing forestry and wetland research and encourage conservation and restoration } \\
\text { of ecosystems critically threatened by climate change }\end{array}$ \\
\hline
\end{tabular}


Appendix 1. Continued

\begin{tabular}{|c|c|}
\hline Sector & Strategies suggested in the draft policy \\
\hline \multirow{4}{*}{$\begin{array}{l}\text { Biodiversity and } \\
\text { ecosystems }\end{array}$} & Identify biodiversity hotspots where only restricted development should be allowed \\
\hline & Encourage collaborative management and sustainable use of biodiversity and ecosystems \\
\hline & $\begin{array}{l}\text { Promote payment for ecosystem services and streamline other ecosystem benefit-sharing } \\
\text { schemes }\end{array}$ \\
\hline & $\begin{array}{l}\text { Ensure that any human activity within the vicinity of protected areas does not compromise the } \\
\text { integrity of the ecosystem }\end{array}$ \\
\hline \multirow[t]{9}{*}{ Health } & $\begin{array}{l}\text { Conduct assessments within the health sector of vulnerability to climate change, with a view to } \\
\text { developing climate change-resilient health systems }\end{array}$ \\
\hline & Assess the impacts of climate change on human health and well-being \\
\hline & Improve the capture, management, storage and dissemination of health information \\
\hline & $\begin{array}{l}\text { Heighten the surveillance of disease outbreaks and provide subsequent rapid responses to } \\
\text { control epidemics }\end{array}$ \\
\hline & $\begin{array}{l}\text { Strengthen public health systems by building hospitals and supplying them with medicine, } \\
\text { equipment and well-trained personnel }\end{array}$ \\
\hline & $\begin{array}{l}\text { Make provisions for a safe water chain and sanitation facilities to limit outbreaks of water-borne } \\
\text { diseases, and implement strong public awareness programs to promote better hygiene }\end{array}$ \\
\hline & $\begin{array}{l}\text { Increase the health workforce's awareness of and sensitivity to the relationship between climate } \\
\text { change and human health }\end{array}$ \\
\hline & Develop further support action plans against HIV/AIDS \\
\hline & $\begin{array}{l}\text { Create 'green spaces' in urban centers to moderate temperatures and provide fresh air for } \\
\text { healthy living }\end{array}$ \\
\hline \multirow[t]{5}{*}{ Energy } & $\begin{array}{l}\text { Promote and participate in water resource regulation to ensure the availability of water for } \\
\text { hydropower production }\end{array}$ \\
\hline & $\begin{array}{l}\text { Promote and participate in water catchment protection as part of hydroelectric power } \\
\text { infrastructure development }\end{array}$ \\
\hline & $\begin{array}{l}\text { Diversify energy sources by promoting the use of alternative renewable energy sources (such as } \\
\text { solar, biomass, mini-hydro, geothermal and wind) that are less sensitive to climate change }\end{array}$ \\
\hline & $\begin{array}{l}\text { Promote energy-efficient fuelwood cooking stoves and solar and liquefied petroleum gas (LPG) } \\
\text { cookers }\end{array}$ \\
\hline & $\begin{array}{l}\text { Conduct research to determine the potential impacts of climate change elements such as } \\
\text { rainstorms on the country's power supply chain }\end{array}$ \\
\hline \multirow{8}{*}{$\begin{array}{l}\text { Human settlements } \\
\text { and social } \\
\text { infrastructure }\end{array}$} & $\begin{array}{l}\text { Promote proper planning of urban centers by encouraging the adoption of urban planning } \\
\text { principles and standards to make urban areas more resilient to climate change }\end{array}$ \\
\hline & $\begin{array}{l}\text { Revise and harmonize structural/building codes and standards, as well as the training on such } \\
\text { standards, taking into account the expected changes in climate }\end{array}$ \\
\hline & $\begin{array}{l}\text { Improve disaster preparedness by increasing the number of well-equipped health facilities, } \\
\text { constructing dams and dikes in flood-prone areas, and improving disaster preparedness and } \\
\text { management knowledge and skills in regions prone to such climatic disasters }\end{array}$ \\
\hline & Strengthen housing development policies, including subsidies to low-income communities \\
\hline & Establish insurance schemes to provide reparations in regions affected by climatic disasters \\
\hline & Develop climate change awareness programs involving all communities and stakeholders \\
\hline & $\begin{array}{l}\text { Disseminate climate-change and early-warning information in local languages to improve } \\
\text { community disaster preparedness }\end{array}$ \\
\hline & $\begin{array}{l}\text { Diversify economic activities to improve the resilience of rural communities dependent on } \\
\text { climate-sensitive sectors such as agriculture and livestock rearing }\end{array}$ \\
\hline
\end{tabular}


Appendix 1. Continued

\begin{tabular}{|c|c|}
\hline Sector & Strategies suggested in the draft policy \\
\hline \multirow{8}{*}{$\begin{array}{l}\text { Disaster risk } \\
\text { management }\end{array}$} & Develop and implement a climate change-induced disaster risk management strategy \\
\hline & Create an appropriate legal and regulatory framework for disaster management \\
\hline & $\begin{array}{l}\text { Promote vulnerability risk mapping (including the social and economic impacts of climate } \\
\text { change) of the whole country and all sectors }\end{array}$ \\
\hline & $\begin{array}{l}\text { Improve early-warning systems and preparedness to avoid or minimize the adverse impacts of } \\
\text { climate change }\end{array}$ \\
\hline & $\begin{array}{l}\text { Strengthen climate change-induced disaster management institutions at the national and local } \\
\text { levels to reduce causality and ensure preparedness }\end{array}$ \\
\hline & $\begin{array}{l}\text { Provide basic needs to victims of climate change-induced disasters in the form of financial } \\
\text { assistance or donations of food, goods and services as the need arises }\end{array}$ \\
\hline & $\begin{array}{l}\text { Encourage the formation of resident associations that can respond to emergencies, and involve } \\
\text { them in key decision-making }\end{array}$ \\
\hline & $\begin{array}{l}\text { Strengthen the National Emergency Coordination and Operations Centre and establish a } \\
\text { national contingency fund }\end{array}$ \\
\hline \multirow[t]{4}{*}{$\begin{array}{l}\text { Gender issues and } \\
\text { child welfare }\end{array}$} & $\begin{array}{l}\text { Ensure that communities are empowered and that both men and women participate } \\
\text { meaningfully in planning, testing and rolling out adaptation and mitigation activities in rural } \\
\text { and urban areas }\end{array}$ \\
\hline & Ensure that climate change response policies and activities are gender sensitive \\
\hline & $\begin{array}{l}\text { Build on efforts already underway to include gender and climate change in education } \\
\text { curriculum and training programs }\end{array}$ \\
\hline & $\begin{array}{l}\text { Strengthen the capacity of relevant stakeholders at national and local levels to promote gender- } \\
\text { sensitive approaches to climate change adaptation }\end{array}$ \\
\hline \multirow[t]{3}{*}{ Vulnerable groups } & $\begin{array}{l}\text { Make provisions to ensure that vulnerable groups and communities are empowered to } \\
\text { effectively and adequately adapt to the impacts of climate change }\end{array}$ \\
\hline & $\begin{array}{l}\text { Support and encourage vulnerable groups to engage in sustainable adaptation mechanisms to } \\
\text { cope with climate change impacts }\end{array}$ \\
\hline & $\begin{array}{l}\text { Integrate climate change-related issues into economic policies and action plans that address } \\
\text { the needs of vulnerable groups }\end{array}$ \\
\hline
\end{tabular}

Source: GoU (2012) 

CIFOR Working Papers contain preliminary or advance research results on tropical forest issues that need to be published in a timely manner to inform and promote discussion. This content has been internally reviewed but has not undergone external peer review.

Climate change is expected to bring new challenges and opportunities for the livelihoods of rural communities in Uganda, where more than $80 \%$ of the population depends on rain-fed agriculture. The purpose of this review was to analyze national policies on climate change adaptation, agriculture, forests, management of forested and agroforested landscape ecosystems and their goods and services, and the roles of stakeholders in the national arena. Recognizing the role of forest cover in climate change mitigation and adaptation, this review is based on stakeholder engagement and analysis of published literature on the policy, institutional and socioeconomic drivers of forest cover change around Mount Elgon. The bulk of Uganda's forests are on land under private ownership and deforestation has occurred mainly in such forests. Several national laws and international conventions ratified by Uganda offer a framework under which forests are managed. Management of protected forests is shared between central and local authorities. Several natural resource policies are likely to have significant unintended impacts that may enable or limit the adaptation of stakeholders and ecosystems to climate change. The current climate change policy, which is an overarching document that addresses climate change in Uganda, suggests that policy responses, either sector specific or crosscutting in nature, be harmonized in order to better address the challenges associated with climate change adaptation and mitigation.

RESEARCH PROGRAM ON

Forests, Trees and Agroforestry
This research was carried out by CIFOR as part of the CGIAR Research Program on Forests, Trees and Agroforestry (CRP-FTA). This collaborative program aims to enhance the management and use of forests, agroforestry and tree genetic resources across the landscape from forests to farms. CIFOR leads CRP-FTA in partnership with Bioversity International, CATIE, CIRAD, the International Center for Tropical Agriculture and the World Agroforestry Centre.

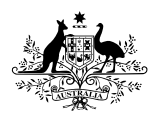

